\title{
Mesoscale distribution patterns of macrozooplankton communities in Prydz Bay, Antarctica - January to February 1991
}

\author{
G. W. Hosie, T. G. Cochran \\ Australian Antarctic Division, Channel Highway, Kingston, Tasmania 7050, Australia
}

\begin{abstract}
Previous large-scale surveys of the Prydz Bay region (Antarctica) have identified the continental shelf edge of Prydz Bay as an area of rapid transition between 3 major zooplankton communities. One of these communities is dominated by the Antarctic krill Euphausia superba. This community was located mainly along the continental shelf edge, usually between the offshore main oceanic community dominated by copepods and chaetognaths, and the neritic community dominated by E. crystallorophias. In January to March 1991, the Prydz Bay continental shelf area was the subject of a more intensive mesoscale survey to more accurately define the distribution patterns of the 3 zooplankton communities in that area. Cluster analysis and non-metric multidimensional scaling were used to define the communities, their distributjon patterns, indicator species and species affinities. The composition of the communities were much the same as previously defined. E. superba again exhibited a distinct dissociation from all other species. However, the distribution pattern of the krill-dominated community was different from those previously observed. That community did not separate the copepod-and E. crystallorophias-dominated communities in Prydz Bay and apparently was displaced to the west. Temperature was strongly correlated with the zooplankton community distribution patterns, suggesting that temperature has more influence at the mesoscale level than at larger scales. Sea ice patterns, chlorophyll a abundance and salinity were also correlated, to a lesser extent, with the community distribution patterns.
\end{abstract}

KEY WORDS: Macrozooplankton · Communities · Antarctic

\section{INTRODUCTION}

The Antarctic krill Euphausia superba is perhaps the most important single species in the Antarctic marine ecosystem, in terms of its high abundance and position in the food web. It is, however, not the only important or dominant taxon in that ecosystem. Copepods collectively can form a significant component of the zooplankton biomass, at times exceeding that of the krill (Everson 1984, Smith \& Schnack-Schiel 1990, Conover \& Huntley 1991). In the Indian Ocean and Pacific Ocean sectors, herbivorous copepods represented 66 to $73 \%$ of the zooplankton biomass (Voronina 1967. Hopkins 1971, Yamada \& Kawamura 1986). In areas of low phytoplankton abundance and high copepod biomass, copepods consumed $55 \%$ of daily primary production (Schnack et al. 1985). Conover \& Huntley
(1991) suggested, on the basis of conservative abundance estimates, that Antarctic copepods must consume at least 3 times, perhaps as much as 8 times, the primary production eaten by krill. Moreover, copepods form an important alternative pathway in the food web. Pleuragramma antarcticum feeds extensively on copepods (Kellermann 1987. Hubold \& Ekau 1990, Boysen-Ennen et al. 1991). In turn, this fish is a conspicuous component in the diet of vertebrate predators (Williams 1985, 1989, Green \& Williams 1986). E. crystallorophias is another zooplankton species important in the diet of fish and birds (Williams 1985, 1989, Foster et al. 1987, Puddicombe \& Johnstone 1988). Numerous other zooplankton taxa are important dietary components of the nototheniid fish Pagothenia borchgrevinki, e.g. the pteropod Limacina helicina, the hyperiid Hyperiella dilatata, gammarids, chaetognaths, and 
copepods (Foster et al 1987). In order to fully understand the various pathways in the food web, and the possible interactions between krill and other zooplankton species, detailed knowledge of the community ecology is required. This involves defining the number of communities in an area, their composition, the dominant species or indicator species, species affinities, distribution patterns and, where possible, the environmental parameters that control these patterns. There have been few such studies carried out around Antarctica and mostly in somewhat unique specific areas of the Atlantic sector. Boysen-Ennen \& Piatkowski (1988), Hubold et al. (1988) and Piatkowski (1989a) primarily focussed on the coastal regions of southern and eastern Weddell Sea. Piatkowski (1989b) attempted to relate the complex zooplankton distribution patterns off the Antarctic Peninsula to the hydrography of the region which he described as more complex than that of other parts of Antarctica. Siegel \& Piatkowski (1990) studied the seasonal variability in the community patterns in this area. Their work is one of few such studies in the Atlantic sector. The study by Atkinson et al. (1990) on seasonal variability of zooplankton patterns and oceanographic processes was the culmination of a number of studies by the British Antarctic Survey on the zooplankton in the waters around South Georgia. South Georgia is located close to the Polar Front and, not surprisingly, sub-antarctic species predominated (Atkinson et al. 1990).

A few zooplankton studies have been carried out in the Prydz Bay region, Antactica. Many were limited in terms of the taxa examined, the level of identification, the number of study sites or the level of community description, i.e. distribution of abundance only (Zmijewska 1983, Boden 1985, Yamada \& Kawamura 1986, Budnichenko \& Khromov 1988, Pakhomov 1989). Yamada \& Kawamura (1986) looked at within-season variability of the abundance for some copepod species from 6 sites in the Prydz Bay region between $62^{\circ}$ and $64^{\circ} \mathrm{S}$. During the international BIOMASS program (Biological Investigations of Marine Antarctic Systems and Stocks), Japan also conducted studies on the distribution and/or abundance of copepods, chaetognaths and euphausiids to the east of the Prydz Bay region south of Australia (Kawamura 1986, Terazaki \& Wada 1986. Terazaki 1989). Zooplankton studies were also carried out west of the region in the inshore margins around Syowa station (e.g. Fukuchi et al. 1985, Tanimura et al. 1986).

There has been 1 study, so far conducted, that has attempted a detailed analyses of the zooplankton community ecology of the Prydz Bay region (Hosie 1994), analogous to those studies carried out in the Atlantic sector as mentioned above. Four large-scale surveys were undertaken as part of that study, which identified
3 zooplankton communities in the shelf edge area of Prydz Bay. A neritic community was located in the southern part of the Prydz Bay continental shelf, dominated by Euphausia crystallorophias, gammarids and larvae of the fish Pleuragramma antarcticum. A main oceanic community was prevalent in the region north of the shelf edge to approximately $62^{\circ}$ to $63^{\circ} \mathrm{S}$, with the major components being copepods, chaetognaths, siphonophores and the euphausiid Thysanoessa macrura. The third community was characterized by the high abundance and dominance of the Antarctic krill $E$. superba and also by the paucity of zooplankton. This community was mainly located along the continental shelf edge, usually between the main oceanic and neritic communities.

The continental shelf edge of Prydz Bay was thus identified as an area of particular interest because of the dominance of krill, but also as an area of rapid transition between 3 major communities. Unfortunately, the sampling resolution of the shelf region in those earlier surveys was perhaps not ideal for accurately defining the distributions of these communities. The previous 4 surveys in 1981, 1982, 1985 and 1987 concentrated more on initially studying the suspected larger-scale distributions of adult krill (Marr 1962, Mackintosh 1973, Lubimova et al. 1985, Hosie et al 1988), and the larvae of krill and other euphausiids (Hosie 1991). In January to March 1991, the Prydz Bay-continental shelf area was the subject of a more intensive mesoscale survey (as defined by Haury et al. 1977), with the prime objective of more accurately defining the distributions and boundaries of the 3 main zooplankton communities in that area. The species composition and affinities, and distribution patterns of the communities were defined by the same multi- and univariate analytical techniques used in the previous study of the zooplankton community ecology of the greater Prydz Bay region (Hosie 1994). The patterns defined in the present study were compared with various environmental parameters to determine which factors govern the zooplankton distributions. The distribution of the krill-dominated community in relation to the shelf edge was of particular interest. We accepted Mills' (1969) definition of a community for the purposes of this study: a community is a group of organisms occurring in a particular environment, presumably interacting with each other and with the environment, and separable from other groups by means of ecological surveys

\section{METHODS}

Sampling procedures. The Prydz Bay-continental shelf study area was defined for the present purpose 


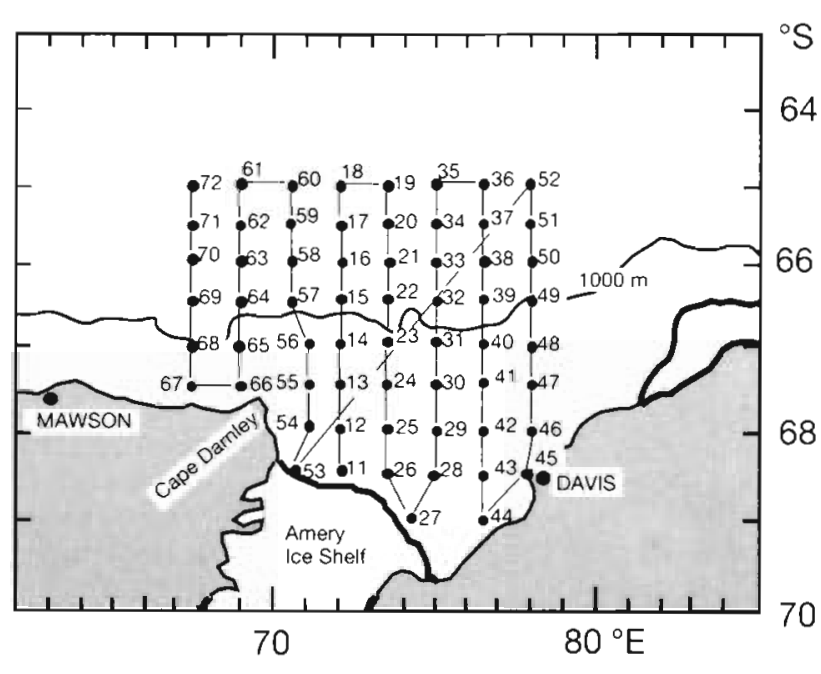

Fig. 1. Cruise track of RSV 'Aurora Australis', 19 January to 14 February 1991, showing net sampling sites and the $1000 \mathrm{~m}$ water depth contour

as being from $67^{\circ} 30^{\prime}$ to $78^{\circ} \mathrm{E}$ and south from $65^{\circ} \mathrm{S}$ to the coast of Antarctica or Amery Ice Shelf. Sampling sites were located at 30 nautical mile intervals along 8 longitudinal transects which were $1.5^{\circ}$ of longitude apart (Fig. 1). Sampling commenced on 19 January 1991 in the south of Prydz Bay at Stn 11 - then progressed eastward to Stn 52 in the northeast. Sampling continued from Stn 53, again in the south of the bay, before progressing westward and finishing at Stn 72 on 14 February 1991. Sampling was originally planned to start along the western transect $67^{\circ} 30^{\prime} \mathrm{E}$, then continuing eastward. However, heavy pack-ice (9-10/10 cover) extended from Mawson, through the western part of the study area, to at least $71^{\circ} \mathrm{E}$. Sampling therefore started further east on the first relatively ice-free transect, $72^{\circ} \mathrm{E}$. The pack-ice around Cape Darnley persisted throughout the sampling period and was the reason for the course deviation along transect $70^{\circ} 30^{\prime} \mathrm{E}$, between Stns 53 and 57 . Zooplankton were collected at each sampling site in a 0 to $200 \mathrm{~m}$ downward oblique haul using a Rectangular Midwater Trawl (RMT 8) with a nominal mouth area of $8 \mathrm{~m}^{2}$ and mesh size of $4.5 \mathrm{~mm}$ (Baker et al. 1973). The last $1.8 \mathrm{~m}$ of the net had a mesh of $1.5 \mathrm{~mm}$ and the cod end mesh was $0.85 \mathrm{~mm}$. Siegel (1986) noted that an RMT 8 with $4.5 \mathrm{~mm}$ mesh may undersample krill less than $20 \mathrm{~mm}$ in length. Small zooplankton, especially copepods, also would have been undersampled, although the finer meshes at the end of the net and cod end did retain substantial numbers of copepods to permit relative comparison of abundances between sample sites.

An electro-mechanical net release and real-time depth sensor was mounted above the net. The net was thus opened just below the surface and then closed at $200 \mathrm{~m}$, or within $20 \mathrm{~m}$ of the sea floor in shallower water. The net was equipped with a flowmeter, and in calculating the volume filtered, the effects of towing speed and trajectory were taken into account (Roe et al. 1980, Pommeranz et al. 1982).

Basic sorting of taxa was carried out on board ship. In particular, specimens of Euphausia superba were removed, as well as large and fragile zooplankton (jellyfish, salps, etc.). All specimens were preserved in Steedman's solution (Steedman 1976) for later examination in the Antarctic Division laboratories where specimens were identified to the species level where possible and counted. For the purposes of this study, macrozooplankton were defined as all species collected by the RMT 8 . Unlike the previous macroscale surveys (Hosie 1994), ichthyoplankton were not included in the present analyses. Ichthyoplankton are the subject of another more detailed study on fish ecology in Prydz Bay (Williams 1992). Euphausiid larvae were also not included in the analyses. They were collected by other more efficient means and are also the subject of a separate more detailed study.

At each sampling site, water samples were collected for phytoplankton pigment analysis, at depths of $0,15,30,45,60,75,90,105,120,135$ and $150 \mathrm{~m}$, using a General Oceanics rosette sampler with twelve 51 Niskin bottles. The chlorophyll a (chl a) level in each bottle was determined on board using a Turner Designs TD10 fluorometer. A Neil Brown Mark 3 CTD was mounted on the rosette which provided continuous profiles of conductivity/salinity and tem. perature.

Data analyses. A species by sampling site matrix, expressed as density values of number of individuals $1000 \mathrm{~m}^{-3}$, was analysed using both cluster analysis and non-metric multidimensional (NMDS) ordination. Sampling sites were first compared to define areas with similar species composition (q-type analysis). Multivariate and univariate statistical tests were subsequently applied to test the validity of observed patterns and to relate these patterns to environmental parameters. The inverse comparison analysis of species data (r-type analysis) was also undertaken to define species associations or affinities. A flow chart summarizing the numerical analyses is shown in Fig. 2 and is primarily a modification of the methodology recommended by Field et al. (1982) and Kruskal \& Wish (1978). Multivariate analyses were carried out using BIOETAT II (R. A. Pimental \& J. D. Smith 1985, Sigma Soft, Placentia, CA, USA).

Prior to the comparison of sampling sites, data was transformed using the $\log _{10}(x+1)$ function to reduce the bias of very high abundance species and to give more weighting to species likely to have been undersam- 


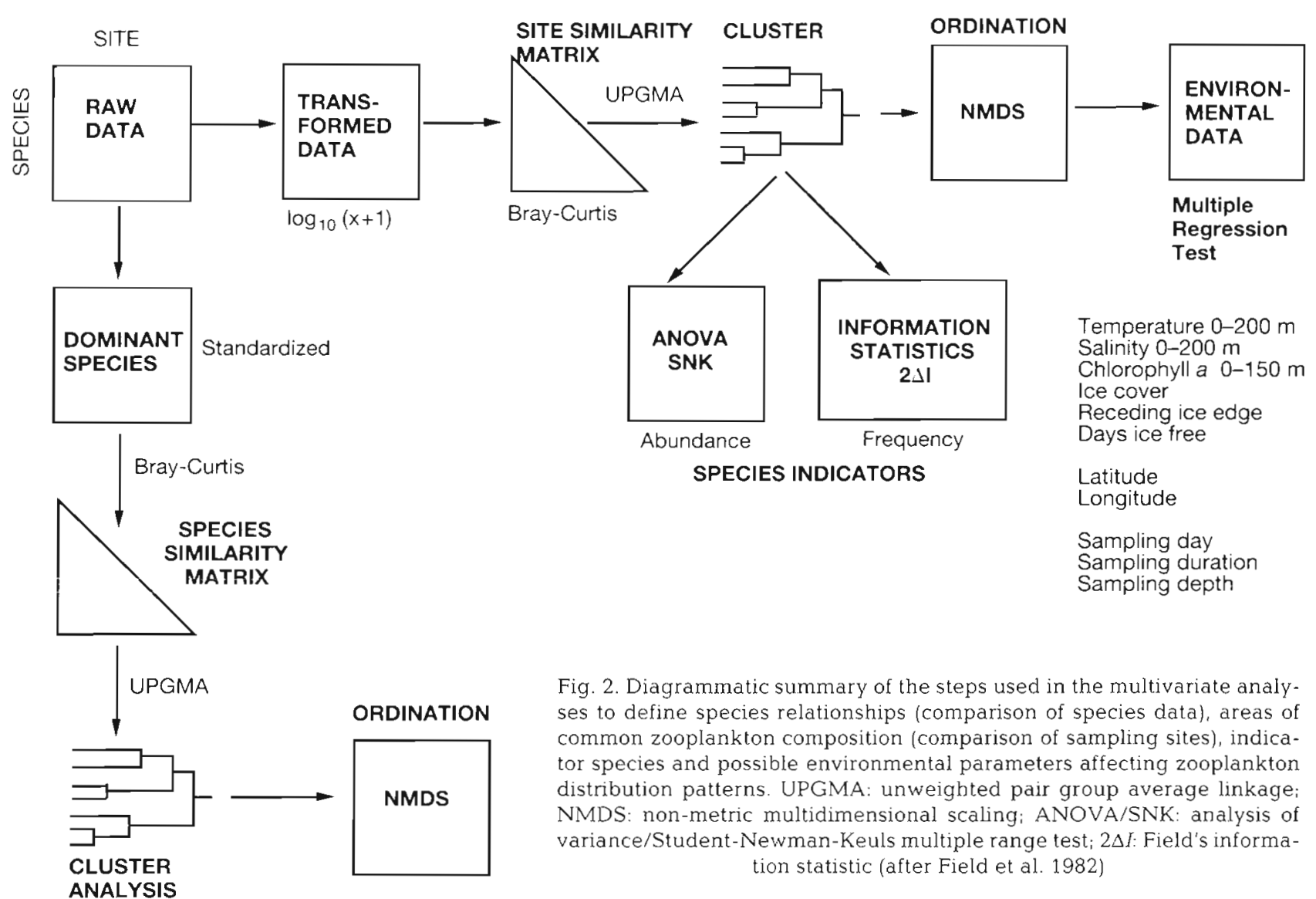

pled, e.g. copepods. Cluster analysis was carried out first using the Bray-Curtis dissimilarity index (Bray \& Curtis 1957) coupled with unweighted pair group average linkage (UPGMA). Bray-Curtis index was chosen because of its ability to deal with matrices with a high component of zero data entries, i.e. it is not influenced by joint absences (Field et al. 1982).

Sampling site cluster groups identified by the cluster analysis were further analysed to define indicator species which characterised each site group. Two types of indicator species were defined. The first type consisted of species which distinguished cluster groups by their frequency of occurrence, i.e. they were more frequent in one cluster group than another. These 'frequency' type indicators were defined using Field's information statistic $\left(2 \Delta I_{i}\right)$ (Field et al. 1982). Every taxon (species), $i$. was compared between 2 cluster groups by the following formula:

$$
2 \Delta I_{1}=2\left(I_{\mathrm{ti}}-I_{11}-I_{2 i}\right)
$$

where $I_{t}=$ total information content of both cluster groups combined $=N_{\mathrm{t}} \log N_{\mathrm{t}}-A_{\mathrm{u}} \log A_{11}-\left(N_{\mathrm{t}}-A_{\mathrm{u}}\right)$ $\log \left(N_{\mathrm{t}}-A_{1}\right) ; N_{\mathrm{t}}=$ no. of samples in both cluster groups together ('potential presences'); $A_{t}=$ no. of samples in which Species $i$ is actually present; $\left(N_{i}-A_{t i}\right)=$ number of samples from which Species $i$ is absent. Similarly, the information content $I_{1 i}$ and $I_{2}$, are obtained for Clusters 1 and 2 respectively. Field's information statistic basically provides an index of the degree of difference in the frequency of occurrence of a species between 2 cluster groups, in relation to the number of sites. The resulting $2 \Delta I_{j}$ values were compared with $\chi^{2}$ values at 5 and $1 \%$ probability levels for 1 degree of freedom, on the premise that $2 \Delta I_{i}$ approximates a $\chi^{2}$ distribution (Field et al. 1982).

Quite often a species was common to 2 or more site cluster groups, but had a significantly higher abundance in one particular group. Therefore, the second type of species indicator comprised species that distinguishes a group by their higher abundance. These 'abundance' indicator species were defined by analysis of variance and further tested for significance using the Student-Newman-Keuls (SNK) multiple range test (Zar 1984). To avoid spurious, low abundance, rare indicator species, and also to reduce computing time, only numerically dominant species were used in the ANOVA. These dominant species were the same as those defined and used in the comparison of species (see below). Reliable indicator species should ideally be abundant. 
Following the cluster analyses the data sets were further subjected to non-metric multidimensional scaling (NMDS) ordination. This analysis provided a view or 'map' of the sampling site similarities in 2-, 3- or 4dimensional space, in addition to the cluster analysis dendrogram which is fundamentally 1-dimensional. NMDS is considered to be one of the most robust ordination techniques available, especially in coping with a large number of zero counts (Field et al. 1982, Gray et al. 1988). Another advantage of NMDS is that a 'stress' value is produced for each ordination $(4,3,2$ axes), indicating the goodness-of-fit between the original data and the derived 'map'. The lower the value, often expressed between 0 and 1 , the better the fit. The stress value was then used, via the graphical-inflection method of Kruskal \& Wish (1978) to select the least number of axes which adequately summarises the data set. In this study, a 2 -axes ordination was found to suffice.

Prior to ordination, 'outlier' sample sites identified by cluster analysis were removed from the data set to obviate problems associated with such outliers, e.g. biasing or dominating the ordination, often compressing the distribution of the remaining sites (Gauch 1982). Outliers are sites with a peculiar species composition and thus have a very low similarity with other sites.

New ordination scores derived from the NMDS were compared by multiple regression analysis with various environmental parameters to determine which of these parameters may best explain the zooplankton distributions. The environmental parameters compared were: integrated temperature and salinity between 0 and $200 \mathrm{~m}$ using $2 \mathrm{~m}$ intervals; chl a integrated for 0 to $150 \mathrm{~m}$; pack-ice cover in tenths; receding ice edge; and the time that a site was ice free. There are distinct thermoclines throughout the region and haloclines in the waters of the continental shelf (Smith et al. 1984, Kerry et al. 1987, Middleton \& Humphries 1989). However, there was no knowledge of where zooplankton were distributed in the water column in relation to these structures. Zooplankton abundances were integrated for the upper $200 \mathrm{~m}$ by the oblique trawls. Instead, integrated salinity and temperature values were used as indicative scores of general oceanographic patterns, e.g. horizontal thermal gradients and fronts (Brandt \& Wadley 1981), for the purpose of comparison with zooplankton NMDS scores. The receding ice parameter was defined as the time in days from when the packice was at its most northerly extent, taken as mid-October, to when the ice had receded or dissipated exposing the sampling site. The presence and duration of pack-ice cover is an important factor affecting the structure of the food web (Smith \& Schnack-Schiel 1990). This influence comes firstly from the rotting early summer ice which provides a favourable substrate, which facilitates high production of ice algae, and thus is an important and rich food source for krill and zooplankton (Smetacek et al. 1990). Secondly, as the ice recedes the melt water stabilizes the surface water layers where phytoplankton blooms rapidly develop (Hart 1942, Smetacek et al. 1990). The receding ice parameter thus provides some indication of the sequential start of phytoplankton activity. Similarly, the ice free parameter gives some indication of the time since that start, at each site. Pack-ice cover was estimated at the time of net sampling and ice recession was measured from the Northern Ice Limit maps produced weekly by the U.S. Navy-NOAA Joint Ice Center (Navy Polar Oceanography Center, Suitland, MD, USA), as well as consulting the Antarctic Division Antarctic Sea Ice Extent database (Jacka 1983). Sampling methodology may cause variation in the zooplankton data. Hence, sampling day, the time since the start of a survey, duration of the haul, and sampling depth were included in the regression analyses. Although the same sampling strategy was attempted at each site, the duration of the haul did vary according to ship's speed, the rate the towing wire was paid out, and the rate of descent by the net. Sampling depth was normally 0 to $200 \mathrm{~m}$ but was dependent on water depth. Time of day was not included in the analysis because of the limitations of tests to resolve satisfactorily angular-linear correlations (Zar 1984). Latitude and longitude of sampling sites were also compared with the ordination scores to ascertain the type and degree of zonation in the distributions. The actual multiple regression analysis involved treating each parameter as the dependent variable and the ordination scores for each axes, which are a collective summary of the ecological data, as the independent variables. The direction of maximum correlation of the regression line is at an angle $\theta_{r}$ with the $r$ th axis. The direction cosine, or regression weight, $c_{r}$, of that angle is derived from the formula of Kruskal \& Wish (1978):

$$
c_{r}=b_{r} / \sqrt{b_{1}^{2}+b_{2}^{2}+\ldots b_{m}^{2}}
$$

where $b_{1}, b_{2}$, etc. are the regression coefficients from the multiple regression $a+b_{1} x_{1}+b_{2} x_{2}+\ldots b_{m} x_{m}$ where $m$ is the number of independent variables $x_{i}$.

Water circulation is one parameter expected to have a substantial effect on the distribution of zooplankton, but cannot be included in the regression analysis. Instead, the geographical distribution patterns of station groups, defined by multivariate analysis, were compared visually with known water currents shown in Fig. 3. Fig. 3a shows the geostrophic water flow 10 to $200 \mathrm{~m}$ ) in the Prydz Bay region derived from CTD data by R. A Nunes Vaz and G. W. Lennon (pers. comm. 1990). Fig. 3b shows a synthesis of other currents, 


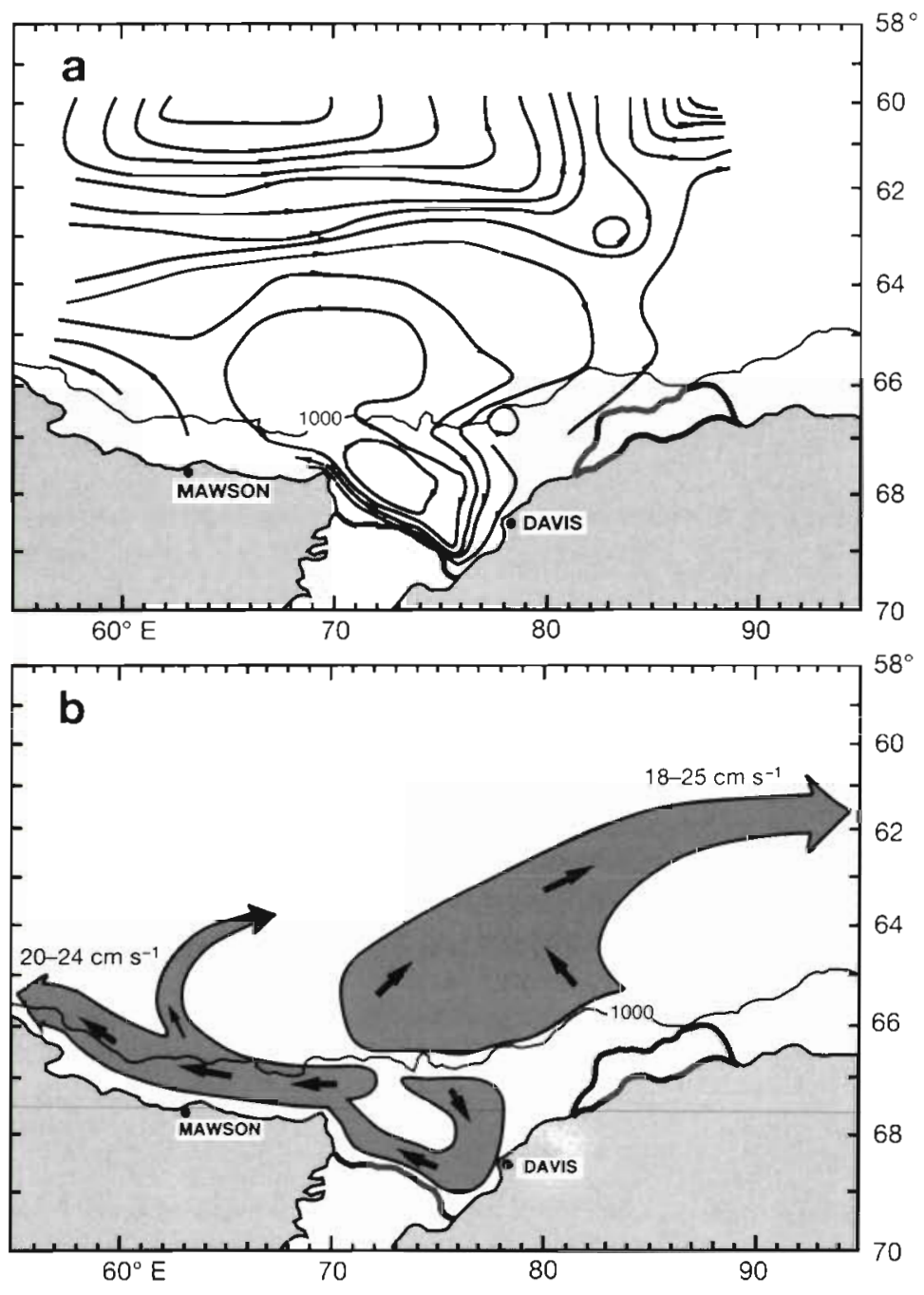

Fig. 3. Horizontal water circulation patterns in the Prydz Bay region. (a) The geostrophic water flow redrawn from the geopotential anomaly contours of R. A. Nunes Vaz and G. W. Lennon (pers. comm. 1990). (b) Apparent dispersal routes of euphausiid larvae, likely to affect zooplankton distributions, determined from sea-ice buoy and iceberg trajectories, current meters and geostrophic flow. Current speeds shown were determined from iceberg trajectories. From Hosie (1991)

known from sea-ice buoys and iceberg trajectories, current meters, as well as geostrophic flow (Fig. 3a), which are believed to influence the distribution of euphausiid larvae (Hosie 1991), but may also affect zooplankton distributions (Hosie 1994).

The inverse analysis of the data sets to define species affinities, also involved cluster analysis as the first step, with Bray-Curtis index and UPGMA linkage, followed by NMDS to map species associations in 2-dimensional space. However, prior to analysis, a data set was reduced to a subset of common dominant species to avoid spurious associations amongst very low abundance rare species, caused by their chance occurrence at 1 site. Following the example of Field et al. (1982), dominant species were defined as those with a $>4 \%$ numerical dominance for any given sampling site. Table 1 lists the 17 species defined. The ctenophore Pleurobrachia pileus was the one new species that was not defined previously as a dominant species in the region (Hosie 1994). Another 5 taxa (Table 1) were previously defined from 1981 to 1987 surveys as numerically dominant in the southern part of the Prydz Bay region and were therefore included in the analysis to determine if species affinities had changed. Appendicularians were also described as dominant in the southern part of the region. Few specimens were collected and from only 2 sites in the present study and hence this taxon was not included. The mesoscale survey did not cover the distribution of the northern oceanic community (NOC), which was generally found north of $63^{\circ} \mathrm{S}$ (Hosie 1994). Therefore, dominant species of the NOC were also not included, i.e. Euphausia frigida, E. triacantha, Salpa thompsoni and Themisto gaudichaudii.

The species data were standardized according to Field et al. (1982), i.e.:

$$
Y_{i j}=100 X_{i j} / \sum_{j=1}^{n} X_{i j}
$$

where $X_{j j}=$ abundance of the $i$ th species in the $j$ th sample $i \sum X_{i j}=$ summed abundance of the $i$ th species over all samples; $Y_{i j}=$ corresponding standardized score.

\section{RESULTS}

\section{Hydrography and chlorophyll a}

Figs. $4 \& 5$ show the horizontal geographic patterns of isotherms and isohalines respectively. Very cold water was found throughout the shelf region. A distinct thermocline occurred at approximately $30 \mathrm{~m}$, occasionally down to $50 \mathrm{~m}$, a result of summer warming of the surface layer - summer surface water. Melting ice produced a very strong halocline coincident with the thermoclines. Below the thermo/haloclines temperature and salinity traces were relatively uniform, temperatures were $<-1.6^{\circ} \mathrm{C}$ and salinity ranged from 34.27 to $34.57 \%$. The coldest surface waters were found in the east of Prydz Bay, i.e. north and south of Davis and in the west around Cape Darnley in association with pack-ice which persisted in those areas throughout the summer (Fig. 4b). Similarly, low surface salinities were observed around the 
Table 1. Dominant species used in the inverse cluster analysis and ordination of species, and also in the ANOVA/SNK analyses to define species indicators. Dominant species were defined as those with a $>4 \%$ numerical dominance for any given sampling site in 1991, or previously defined as dominant in the area in 1981 to 1987 surveys (Hosie 1994)

Taxa with $>4 \%$ numerical dominance in 1991

$\begin{array}{ll}\text { Calanoides acutus } & \text { Ihlea racovitzai } \\ \text { Calanus propinquus } & \text { Limacina helicina } \\ \text { Clio pyramidata } & \text { Metridia gerlachei } \\ \text { Cyllopus lucasii } & \text { Pleurobrachia pileus } \\ \text { Decapod larvae } & \text { Rhincalanus gigas } \\ \text { Euchaeta antarctica } & \text { Sagitta gazellae } \\ \text { Eukrohnia hamata } & \text { Siphonophora (Nectophores) } \\ \text { Euphausia crystallorophias } & \text { Thysanoessa macrura }\end{array}$

Euphausia superba

Taxa defined as dominant 1981 to 1987
Gammaridae

Haloptilus ocellatus

Hyperiella dilatata
Sagitta marri

Tomopteris carpenteri periphery of the Bay (Fig. 5b). There were 3 distinct water masses north of the continental shelf - summer surface water, the Antarctic winter water (WW) and the circumpolar deep water (CDW). As with the shelf region, the summer surface water occupied the upper 30 to $50 \mathrm{~m}$, producing a well-defined seasonal thermocline. Between the summer water and the CDW was the WW. The WW is characterized by temperatures $<-1.5^{\circ} \mathrm{C}$ and salinity in the range of 34.2 to $34.56 \%$ (Smith et al. 1984). The CDW is typically much warmer $\left(0\right.$ to $2{ }^{\circ} \mathrm{C}$ ) producing a second thermocline between 100 and $150 \mathrm{~m}$ depth. The range of mean temperature and salinity values used in the regression analysis were $-1.75^{\circ} \mathrm{C}$ at $\operatorname{Stn} 46$ to $+0.27^{\circ} \mathrm{C}$ at Stn 52, and $33.92 \%$ at $\operatorname{Stn} 53$ to $34.37 \%$ at $\operatorname{Stn} 24$. Individual temperature values ranged from $-2.09^{\circ} \mathrm{C}$ at $<190 \mathrm{~m}$ at Stn 53 to $+2.07^{\circ} \mathrm{C}$ in the surface waters of Stn 36 , and for salinity the range was $31.93 \%$ in the surface waters at $\operatorname{Stn} 47$ to $34.67 \%$ at $190 \mathrm{~m}$ at Stn 58 .

Fig. 6 shows the distribution of mean chl a abundance, integrated for the upper $150 \mathrm{~m}$. Chl a abundances varied considerably in the waters south of the shelf edge, but the highest abundances occurred in this area, especially near the Amery Ice Shelf. Maximum chlorophyll value at each site on the shelf were usually measured in the surface or $15 \mathrm{~m}$ samples, and ranged from $0.13 \mu \mathrm{g} \mathrm{chl} a^{-1}$ at Stn 65 to $7.94 \mu \mathrm{g} \mathrm{chl} \mathrm{a}$ $1^{-1}$ at Stn 27 (mean maxima was $2.35 \pm 2.01 \mu \mathrm{g} \mathrm{chl} \mathrm{a}$ $\mathrm{l}^{-1}, \mathrm{n}=31$ ). Chlorophyll abundances north of the shelf were consistently very low. Chl a maxima in this area ranged from $0.17 \mathrm{\mu g} \mathrm{l}^{-1}$ at Stn 70 to $1.39 \mathrm{\mu g} \mathrm{l}^{-1}$ at
Stn 16 (mean maxima $0.46 \pm 0.25 \mu \mathrm{g} \mathrm{l}^{-1}, \mathrm{n}=29$ ), with the majority of maxima occurring in the $45 \mathrm{~m}$ samples. and occasionally, in the 30,60 and $75 \mathrm{~m}$ bottle samples.

\section{Comparison of sampling sites}

Throughout the following descriptions, principal station cluster groups have been annotated with a number, and where necessary subgroups have a letter suffix, e.g. station Group 1, Group 2a. Capital letters have been used for species cluster groups, e.g. Group A.

An initial cluster analysis of sampling sites showed that there were 3 distinct outlier stations. Stn 42 northwest of Davis had an exceptionally high abundance of Euphausia crystallorophias, 1816 ind. $1000 \mathrm{~m}^{-3}$, which
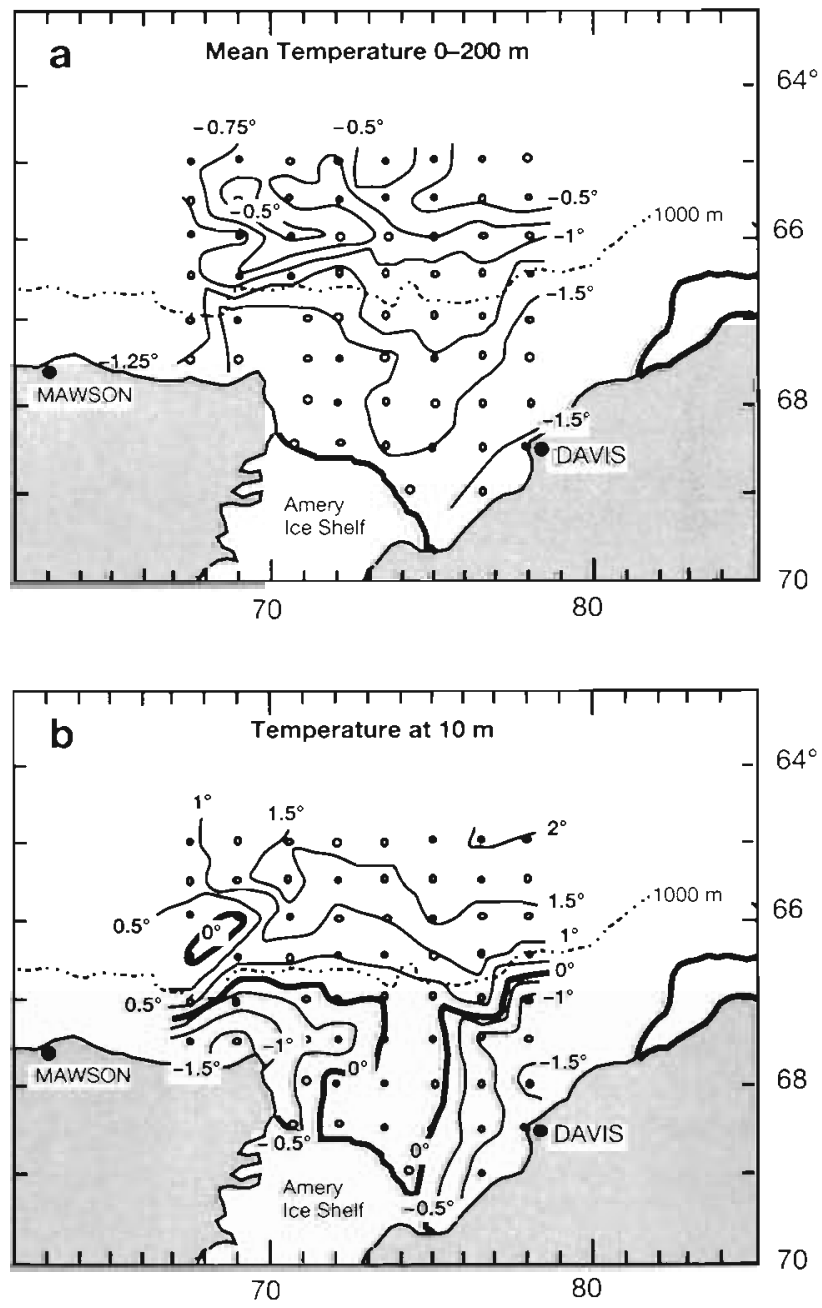

Fig. 4. Geographic pattern of isotherms. (a) Mean 0 to $200 \mathrm{~m}$ isotherms determined by integrating $2 \mathrm{~m}$ recorded intervals. (b) Isotherms at $10 \mathrm{~m}$ depth. Contour lines were calculated and drawn by hand 

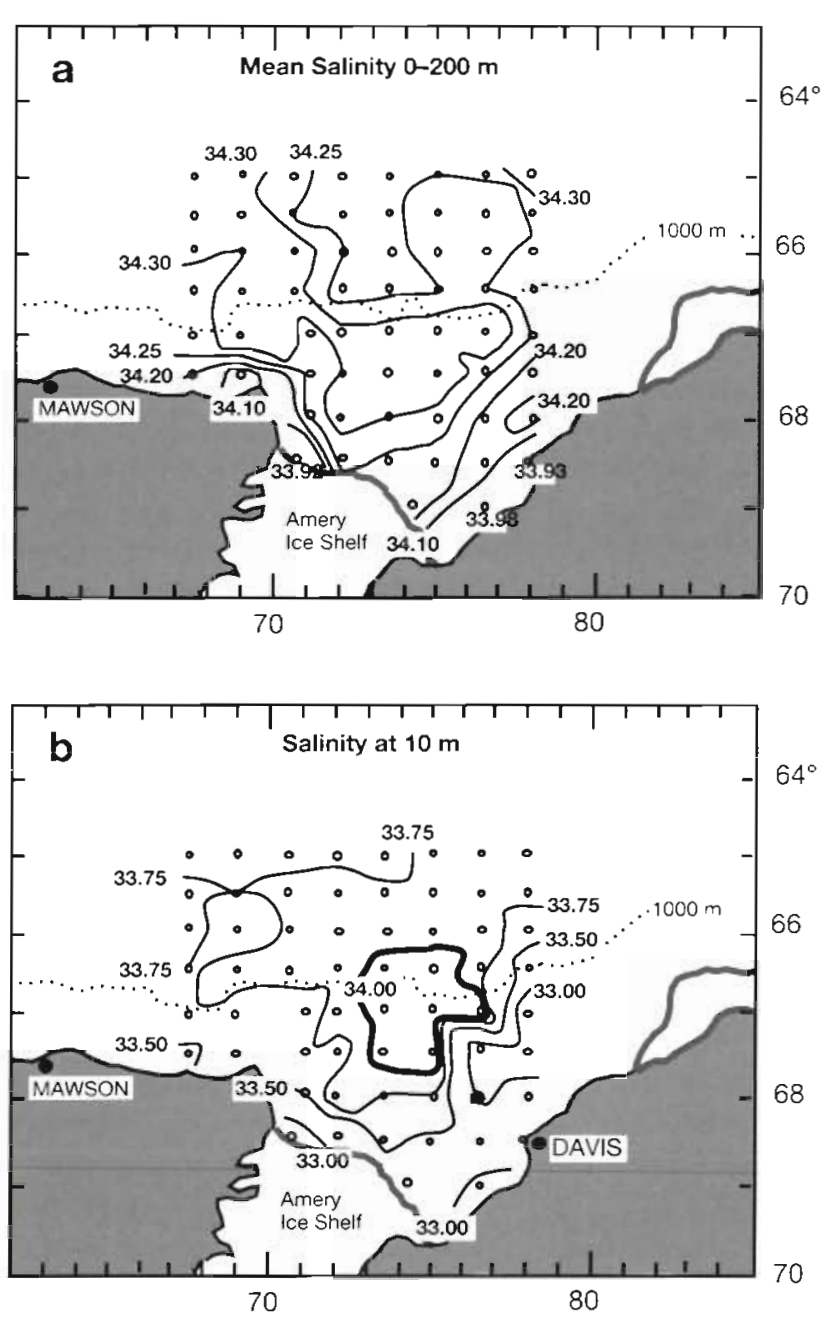

Fig. 5. Geographic pattern of isohalines. (a) Mean 0 to $200 \mathrm{~m}$ isohalines determined by integrating $2 \mathrm{~m}$ recorded intervals. (b) Isohalines at $10 \mathrm{~m}$ depth. Contour lines were calculated and drawn by hand

represented approximately $98 \%$ of the catch both in numbers and wet wt biomass. Stn 57 recorded the highest density of E. superba, 429 ind. $1000 \mathrm{~m}^{-3}$, which represented $97 \%$ of the catch numbers and nearly $99 \%$ of the catch weight. Stn 66 near Cape Darnley was the shallowest sampling site at $148 \mathrm{~m}$. The RMT trawl only sampled down to $120 \mathrm{~m}$. This site was characterised by low numbers of animals, 96 ind. for $2.34 \mathrm{~g}$. the lowest return for any sampling site.

Removal of the outlier sites from the dataset and reanalysis produced 2 distinct cluster groups at the $50 \%$ dissimilarity level and 2 additional major subgroups at $48 \%$ (Fig. 7). The NMDS ordination showed that the 3 groups were quite distinct (Fig. 8). Group 1 comprised the majority of continental shelf stations, while Groups $2 a$ \& $2 b$ were predominantly off-shelf sites separated east-west respectively (Fig. 9). The neritic

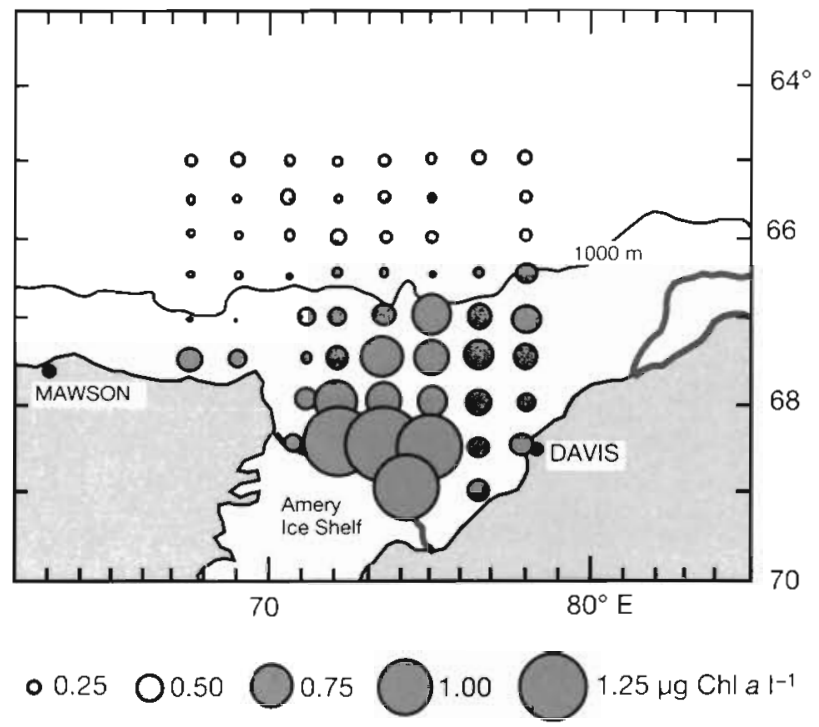

Fig. 6. Distribution of chl a concentrations ( $\left.\mu \mathrm{g} \mathrm{l}^{-1}\right)$, integrated for the upper $150 \mathrm{~m}$ water layer (Dr S. W. Wright pers. comm 1991). Note: chl a abundances were derived from on-board fluorometer measurements

sites were characterized by the euphausiid Euphausia crystallorophias and by gammarids both in terms of frequency of occurrence and high abundance (Tables $2 a$ \& 3). Euchaeta antarctica, Limacina helicina and Hyperiella dilatata were also abundance indicator species of the shelf area (Table 3). Group 2a was distinguished by the high abundance of several species of copepod and chaetognaths, as well as siphonophores, the euphausiid Thysanoessa macrura and by Clio pyramidata (Table 3). Many of these species were also frequency indicator species along with a further 8 numerically minor species (Table $2 b$ ). Group $2 b$ shared a number of indicator species with Group $2 \mathrm{a}$ which also discriminated $2 \mathrm{~b}$ oceanic sites from Group 1 neritic (Table 3). Groups 2a \& 2b did have similar species composition but there was notably lower abundances of these species in Group 2b (Table 3). However, these 2 subgroups were distinguished by the higher frequency of Euphausia superba and Haloptilus ocellatus in Group 2a (Table 2d). The $2 \Delta I$ scores for these species were only significant at the $5 \%$ level. Table 3 shows higher abundances of $E$. superba in Groups $2 a$ \& $2 b$ but was not considered significant, i.e. E. superba was not an abundance species indicator. However, if the 2 oceanic groups are treated together in the ANOVA and SNK analyses then $E$. superba was an abundance indicator discriminating the oceanic region from the neritic $(F=5.96$, df $=1,57, p=0.017$ ). There were no additional indicator species revealed in this treatment from those shown in Table 3. 


\section{Multiple regression}

Fig. 9 shows a clear north-south separation of sampling sites. Latitude, not surprisingly, explained $67 \%$ of the variation of the data in the NMDS ordination (Table 4, Fig. 8). The oceanic groups displayed an east-west separation, and longitude explained $20 \%$ of the data variation almost at right angles to latitude (Fig. 8). The environmental variable that explained most of the variation was temperature $(52 \%)$ and salinity the least $(20 \%)$ (Table 4). A temperature-salinity plot for station groups shows that station Group 1 comprised sites of very cold water, uniformly $<-1.6^{\circ} \mathrm{C}$ below a 30 to $50 \mathrm{~m}$ thermocline, but of variable salinity (Fig. 10). There was little overlap between Group 1 and the 2 oceanic subgroups which occupied areas of higher water temperature and narrower salinity range. The 2 Group 2a sites which overlapped Group 1 were Stns $15 \& 49$. There was no clear separation of the oceanic subgroups in relation to temperature or salinity.

Chl a explained $30 \%$ of the variation in the data, and ice a similar amount. There would seem to be no effect of haul duration or sampling depth on the data, but the time since the start of the sampling ('Sampling Day') did explain $19 \%$ of the data variation (Table 4).

\section{Species associations}

Twenty-two species were included in the inverse cluster analysis of species. Stns 42, 55 \& 66, identified as outliers in the cluster analysis of sampling sites, were removed as the extremely high abundances or unusual catch composition as described above were expected to cause a bias (Gauch 1982).

One major group, and a number of single or double species groups were defined at the $70 \%$ dissimilarity level (Fig. 11).

Group A comprised 15 species, of which 14 were indicator species of the oceanic station Group $2 a$ (Tables 2b \& 3, Fig. 9). Decapod larvae was the one taxon that was not an indicator. In March 1981 deca-

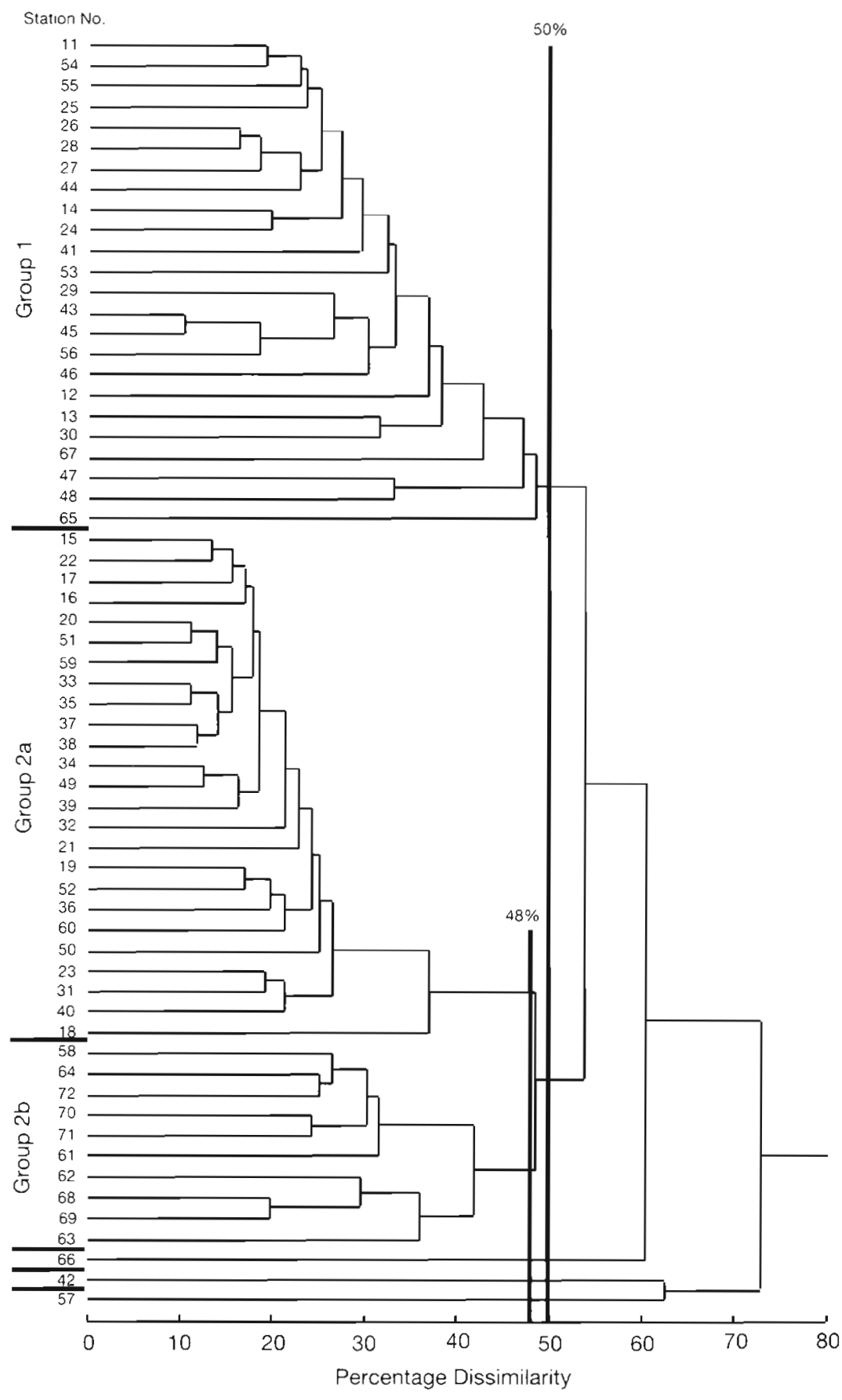

Fig. 7. Dendrogram of cluster analysis comparing zooplankton species composition at each sampling site. The Bray-Curtis dissimilarity index was used for the comparison with UPGMA linkage, after $\log _{10}(X+1)$ transformation of species abundance data

pod larvae of the family Hippolytidae were frequency indicators of the neritic area (Hosie 1994). Decapod larvae in the present study were only numerically abundant in the southern Stn 44 where they comprised $6.7 \%$ of the catch. These larvae could not be identified. The larvae were difficult to identify at many sites, but those that could be identified showed that the larvae of 

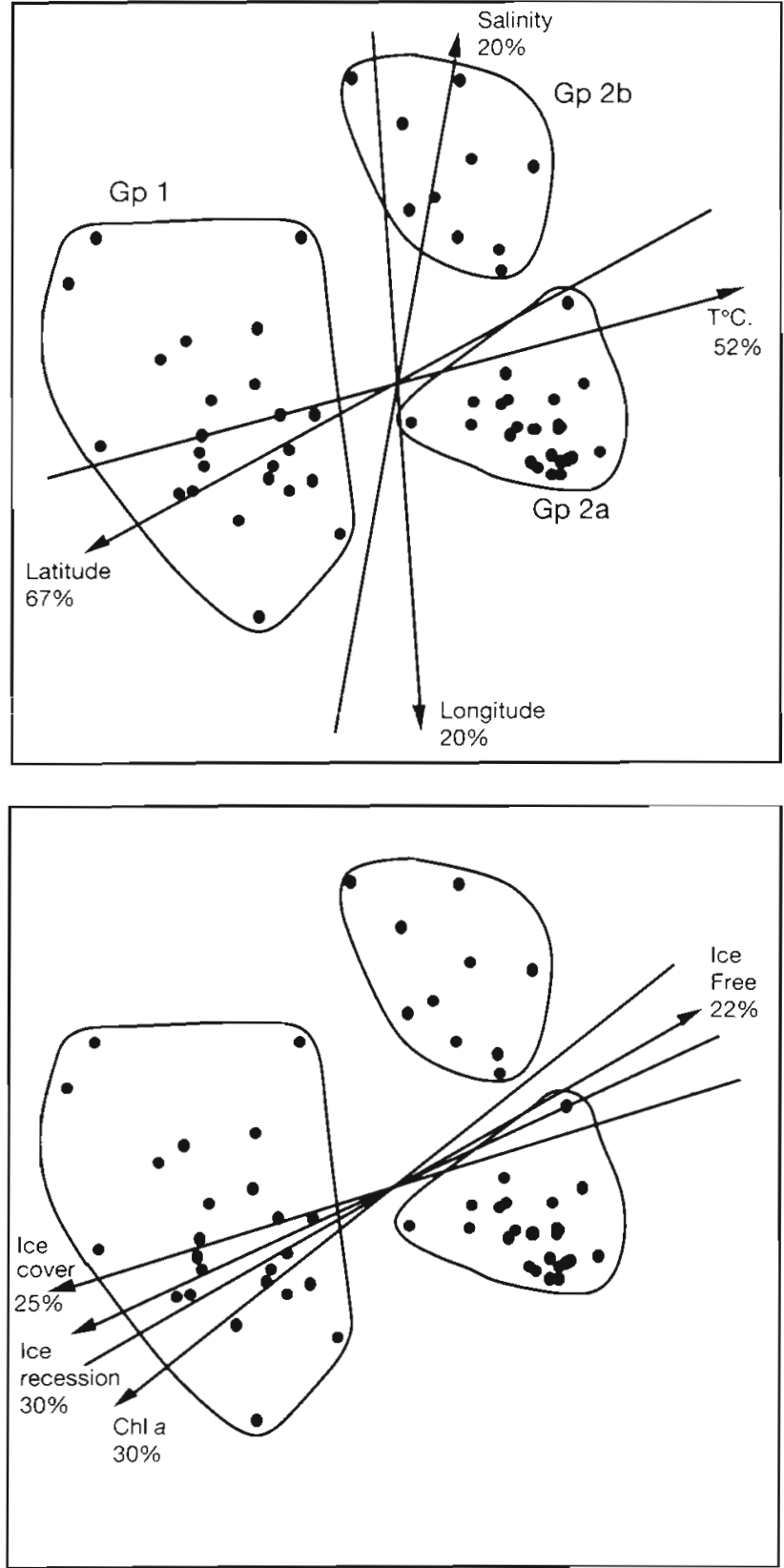

Fig. 8. Ordination plots of the comparison of sampling sites using non-metric multidimensional scaling (NMDS) and Bray-Curtis dissimilarity index. Respective cluster groups identified in Fig. 7 are superimposed. Significant multiple regressions between ordination scores and environmental parameters are shown, as well as the fraction (\%) of variance in the zooplankton data explained by the parameter (see Table 4). Direction of the regression line was determined from Eq. (2). Axis scales are relative in NMDS, based on nonmetric ranking of dissimilarity, and therefore are not shown. Stress value $=0.14$

the Nematocarcinidae were found mainly off the shelf, while those on the shelf were of the family Hippolytidae. Given the likely inshore/offshore differences, the
Table 2. Frequencies of occurrence of indicator species distinguishing cluster groups defined in Fig. 7. Species in each subtable are ranked according to information statistic. Species above the dotted line in each sub-table have $2 \Delta I>6.63(\mathrm{p}=$ $0.01)$, and those below the line have $2 \Delta I>3.84(\mathrm{p}=0.05)$. Maximum possible occurrences are: Group 1 $=24$; Group 2a $=$ 25 ; Group $2 b=10$. 'Species not considered as dominant species and not used in SNK or inverse species analyses

\begin{tabular}{|c|c|c|}
\hline \multicolumn{3}{|c|}{ a. Group 1 (neritic) indicators species } \\
\hline Species & Group 1 & Group 2 \\
\hline Euphausia crystallorophias & 23 & 2 \\
\hline Gammaridae & 12 & 3 \\
\hline \multicolumn{3}{|c|}{ b. Group 2 a (oceanic) indicator species from Group 1} \\
\hline Species & Group 2a & Group 1 \\
\hline Haloptilus ocellatus & 20 & 0 \\
\hline Sagitta marri & 22 & 1 \\
\hline Rhincalanus gigas & 25 & 5 \\
\hline - Heterorhabdus austrinus & 19 & 0 \\
\hline - Calycopsis borchgrevinki & 19 & 1 \\
\hline - Haloptilus oxycephalus & 19 & 1 \\
\hline - Euchirella rostromagna & 18 & 1 \\
\hline Cyllopus lucasii & 16 & 1 \\
\hline - Primno macropa & 16 & 1 \\
\hline "Cephalopoda & 11 & 0 \\
\hline Tomopteris carpenteri & 10 & 0 \\
\hline Thysanoessa macrura & 25 & 16 \\
\hline - Ostracoda & 24 & 14 \\
\hline - Vanadis antarctica & 7 & 0 \\
\hline -Travisiopsis levinseni & 6 & 0 \\
\hline
\end{tabular}

c. Group 2b (oceanic) indicator species from Group 1 Species Group 2b Group 1

\section{- Cephalopoda}

- Calycopsis borchgrevinki

Cyllopus lucasii

- Heterorhabdus austrinus

Rhincalanus gigas

g 0

Haloptilus oxycephalus

- Euchirella rostromagna

$\begin{array}{cc}9 & 1 \\ 9 & 1 \\ 7 & 0 \\ 10 & 5 \\ & \\ 6 & 1 \\ 5 & 1\end{array}$

d. Group 2a indicator species from Group $2 b$

Species

Group 2a Group 2b

None

Euphausia superba

Haloptilus ocellatus

25

19

6

grouping of decapod larvae in Group A was probably spurious. Group B consisted of 2 species, Limacina helicina and Hyperiella dilatata. The NMDS plot (Fig. 12) shows that this group has a close affinity with the oceanic Group A. In the cluster analysis, these 


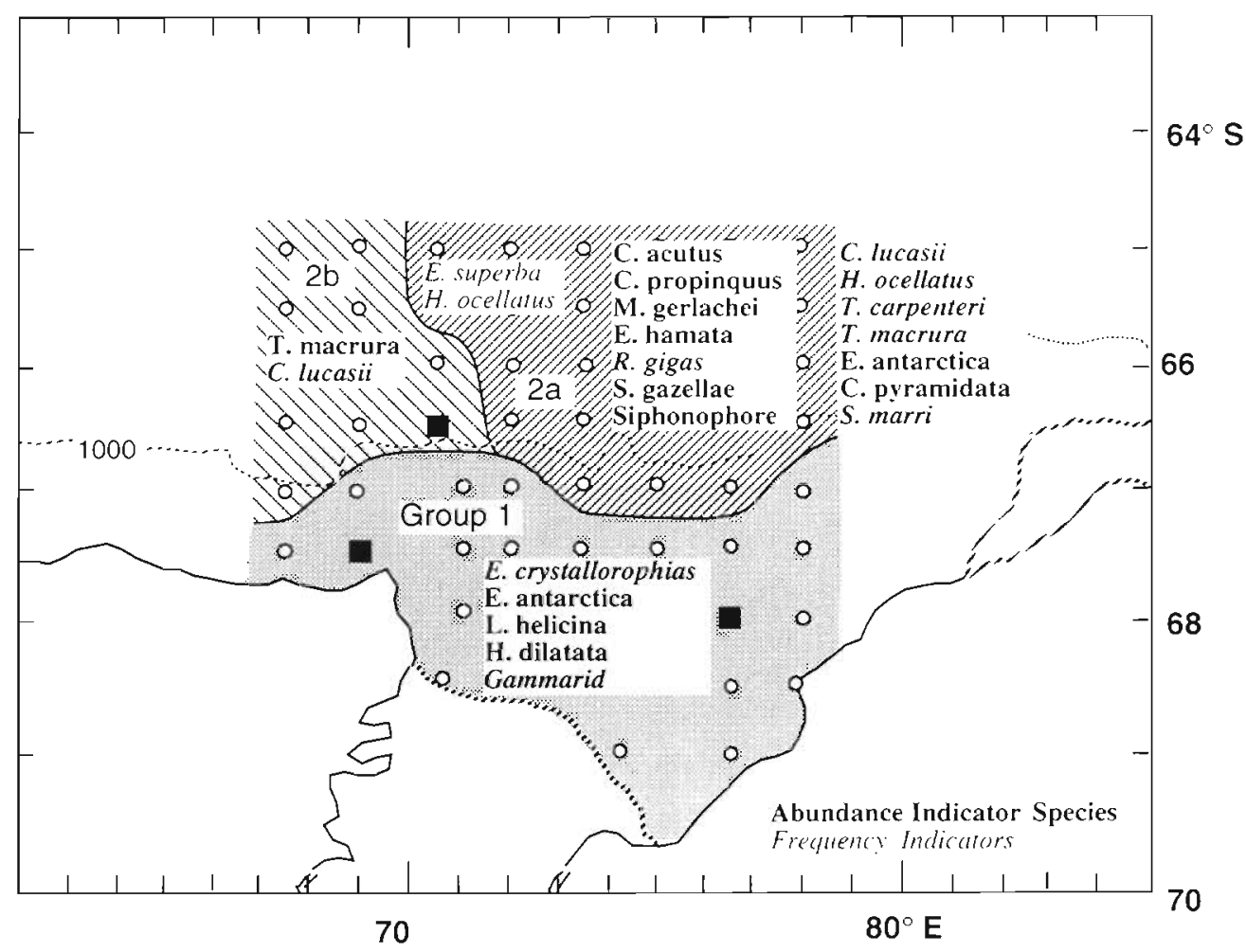

Fig. 9. Geographical distribution of station groups defined by cluster analysis shown in Fig. 7 . Indicator species listed in bold type are those characterizing an area (station group) by their unique higher abundance identified by SNK analysis (Table 3). Indicator species in italic type are those with higher frequency of occurrence in that station group as identified by Field's information statistic (Table 2). Note: in many cases species were both abundance and frequency indicators species. Only dominant species are shown. Each station group is coded with the same shading or pattern corresponding to the zooplankton community, shown in Fig. 13, which dominated that area. = 'outlier' sampling sites not grouped in the cluster analysis

groups were linked at $74 \%$ dissimilarity. However, $L$. helicina and $H$. dilatata were abundance indicators of the neritic station Group 1, and hence the division of groups at $70 \%$ dissimilarity would seem warranted. Euphausia crystallorophias and gammarids were also indicator species of the neritic group of stations (Tables $2 \mathrm{a} \& 3$ ) and thus would be expected to have a closer affinity with Group B than is shown in Fig. 12.

The NMDS plot shows that the ctenophore Pleurobrachia pileus was dissociated from all other species (Fig. 12). It was loosely grouped with Euphausia crystallorophias and gammarid at $86 \%$ in the cluster analysis (Fig. 11). This species was confined to the continental shelf waters where it occurred at 8 of the Group 1 stations and 2 of the oceanic Group 2b sites. Although this species' higher frequency of occurrence inshore was not considered significant in the $2 \Delta I$ analysis, it would still seem to be primarily associated with the neritic zone.

Ihlea racovitzai was not an indicator of any particular area, although it was identified previously as a neritic species in 1981 (Hosie 1994). It would appear more abundant in the neritic zone in this study but was not considered significant (Table 2).
Both the cluster analyses and the NMDS show that Euphausia superba was clearly dissociated from all other species, despite the fact it was, in general, an abundance indicator species of off-shore sites and, specifically, a frequency indicator of station Group 2a.

\section{DISCUSSION}

\section{Species assemblages}

There was good correspondence between the species associations shown in Figs, $9 \& 10$, and indicator species of the station groups. In turn, there was little in the way of any difference in these associations and the composition of zooplankton communities previously described from the macroscale surveys (Fig. 13). For example, species Group A in Fig. 11 contains all of the species that comprise the assemblage defined as the main oceanic community (Fig. 13). Station Group 2a was dominated by these species in significantly high abundances, and clearly represents the main oceanic community. Species Group A also contains Cyllopus lucasii and Tomopteris 
Table 3. Mean abundances, analysis of variance $(F)$ and SNK multiple range tests of dominant species in cluster groups defined in Fig. 7. Analyses were carried out on $\log _{10}(x+1)$ transformed abundances (Zar 1984). Values shown are no. of ind. $1000 \mathrm{~m}^{-3}$ Species with significant differences in mean abundance are shown in bold, while those with significantly higher abundances in a cluster group according to SNK analysis are underlined. For ANOVA p values: " $p<$ $0.05, \cdots p<0.005, \cdots p<0.0005,-$ : not significant. $d f=2,56$

\begin{tabular}{|c|c|c|c|c|c|}
\hline Species & $\begin{array}{c}\text { Group } 1 \\
\text { mean }\end{array}$ & $\begin{array}{l}\text { Group } 2 a \\
\text { mean }\end{array}$ & $\begin{array}{c}\text { Group } 2 b \\
\text { mean }\end{array}$ & b & $\mathrm{p}$ \\
\hline Calanoides acutus & 9.66 & 71.51 & 5.88 & 62.40 & $\cdots$ \\
\hline Calanus propinquus & 4.17 & $\underline{36.60}$ & 2.00 & 72.26 & $\cdots$ \\
\hline Clio pyramidata & 1.23 & 2.05 & 0.70 & 8.70 & $*$ \\
\hline Cyllopus lucasii & 0.004 & $\underline{0.33}$ & 0.31 & 9.30 & $\cdots$ \\
\hline Decapoda larvae & 0.20 & $\overline{0.24}$ & $\overline{0.08}$ & 1.16 & - \\
\hline Euchaeta antarctica & 2.78 & $\underline{3.64}$ & 0.38 & 14.78 & $\cdots$ \\
\hline Eukrohnia hamata & 1.21 & 9.18 & 1.36 & 48.81 & $*$ \\
\hline Euphausia crystallorophias & $\underline{35.02}$ & 0.20 & 0.00 & 54.81 & $\cdots$ \\
\hline Euphausia superba & 0.86 & 19.10 & 12.26 & 2.93 & - \\
\hline Gammaridae & $\underline{0.17}$ & 0.01 & 0.03 & 6.78 & $\cdot \cdot$ \\
\hline Haloptilus ocellatus & 0.00 & 0.20 & 0.01 & 27.76 & $\cdots$ \\
\hline Hyperiella dilatata & 0.19 & 0.05 & 0.04 & 6.96 & $* *$ \\
\hline Ihlea racovitzai & 0.78 & 0.30 & 0.12 & 1.11 & - \\
\hline Limacina helicina & $\underline{0.44}$ & 0.20 & 0.13 & 4.97 & * \\
\hline Metridia gerlachei & 8.02 & 16.30 & 0.56 & 28.52 & $\cdots$ \\
\hline Pleurabrachia pileus & 0.14 & 0.01 & 0.00 & 2.74 & - \\
\hline Rhincalanus gigas & 0.06 & 8.30 & 1.62 & 132.81 & $\cdots$ \\
\hline Sagita gazellae & 1.12 & 7.30 & 2.98 & 76.44 & $\cdots$ \\
\hline Sagitta marri & 0.01 & 0.87 & 0.07 & 32.32 & $* *$ \\
\hline Siphonophore nectophore & 1.14 & 6.98 & 4.42 & 71.64 & $\cdots$ \\
\hline Thysanoessa macrura & 0.39 & 4.69 & $\underline{2.29}$ & 15.89 & $\cdots$ \\
\hline Tomopteris carpenteri & 0.00 & 0.06 & 0.01 & 7.74 & $\because$ \\
\hline
\end{tabular}

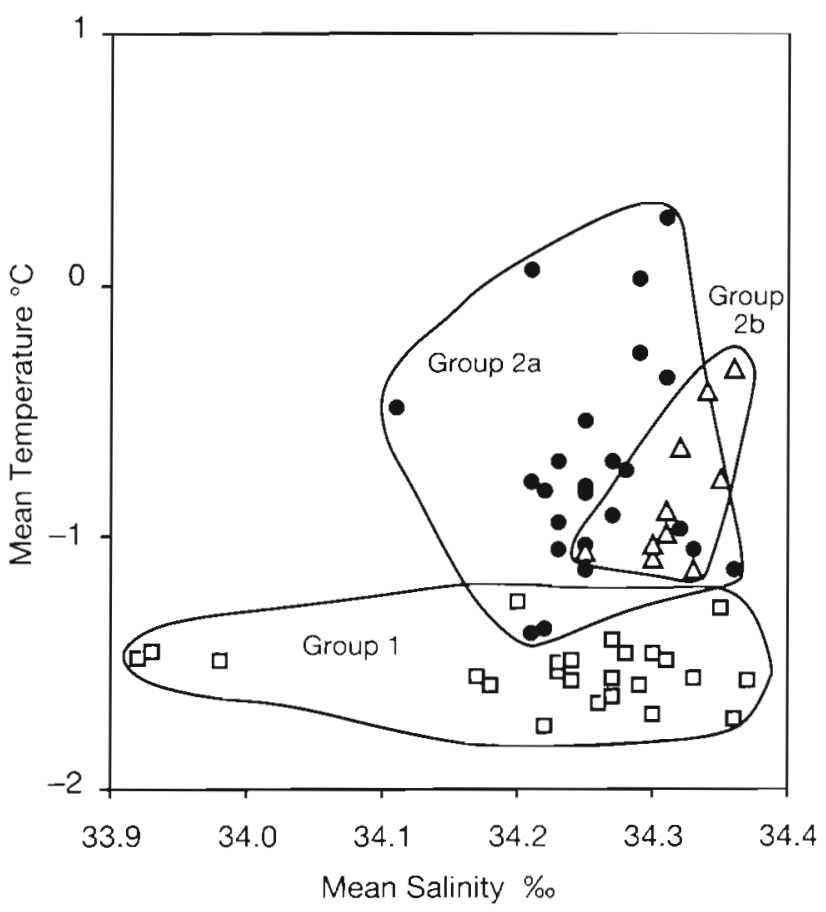

Fig. 10. Temperature-salinity plot for each sampling site using mean values for 0 to $200 \mathrm{~m}$. Station cluster groups identified in Fig. 7 are superimposed carpenteri that were defined as a transition group between the main oceanic and the northern oceanic communities; the latter group was generally confined to waters north of $63^{\circ} \mathrm{S}$.

Appendicularians were also defined as a member of the main oceanic community, but were of course excluded from the present analyses because of their extremely low abundances. The other minor differences in the composition of the main oceanic species affinities between this study and those of the previous macroscale surveys involved decapod larvae and the hyperiid Hyperiella dilatata. $H$. dilatata was originally classified as a member of both the main oceanic and northern oceanic communuties. Some affinity was indicated with the neritic species in November to December 1982 (Hosie 1994). In the present study, $H$. dilatata displayed a more substantial association with the neritic zone, where it was a species indicator. Siegel \& Piatkowski (1990) also noted that this species was indicative of either neritic or oceanic waters, depending on the time of year. The result of the Prydz Bay surveys support Siegel \& Piatkowski's observation that $H$. dilatata is not a reliable indicator species.

Decapod larvae, specifically those of the family Hippolytidae, were defined as indicators of neritic waters in the January to March 1981 survey of the Prydz Bay region (Hosie 1994). The inclusion of decapod larvae with the oceanic species in Group A may be a spurious association caused by the grouping of all decapod larvae as one taxon, despite possible differences in species distributions. For example, the larvae of the Nematocarcinidae, one group that could be identified with confidence, primarily had an oceanic distribution. The decapod larvae were generally low in abundance, and were thus grouped to produce one substantial taxon for analysis. This treatment may not have been valid.

By comparison with the main oceanic community, the neritic community had a much lower diversity of dominant species, with Euphausia crystallorophias being the one species occurring persistently in high abundance in all surveys. Gammarids generally occurred in low abundance, but still formed a close association with E. crystallorophias as seen in Figs. $11 \& 12$ and also in the previous surveys (Fig. 13). While it may not be valid to treat all decapod larvae as one taxon, the same is not true for gammarids, which always have a neritic distribution. 
Table 4. Multiple regression analyses between environmental parameters and NMDS scores for 2-axis ordination of comparison of sampling sites. Regression weights are derived from Eq. (2). Adj. $\mathrm{R}^{2}$ : adjusted coefficient of determination which gives the fraction of the variance accounted for by the explanatory variable (Jongman et al. 1987). For ANOVA $p$ values: ${ }^{*}<0.05, \cdots p<$ $0.005, \cdots p<0.0005$, ns: not significant

\begin{tabular}{|c|c|c|c|c|c|c|}
\hline \multirow[t]{2}{*}{ Variable } & \multicolumn{2}{|c|}{ Direction cosines (regression weights) } & \multirow[t]{2}{*}{ Adj. $R^{2}$} & \multirow[t]{2}{*}{$F$} & \multirow[t]{2}{*}{ df } & \multirow[t]{2}{*}{$\mathrm{p}$} \\
\hline & $X$ & Y & & & & \\
\hline Latitude & -0.875 & -0.484 & 0.669 & 59.655 & 2,56 & $\cdots$ \\
\hline Temperature & 0.966 & 0.257 & 0.520 & 32.366 & 2,56 & $\cdots$ \\
\hline Ice recession & -0.908 & -0.418 & 0.299 & 13.348 & 2,56 & $\cdots$ \\
\hline Chlorophyll a & -0.781 & -0.625 & 0.299 & 12.958 & 2,54 & $\cdots$ \\
\hline Pack ice cover & -0.955 & -0.297 & 0.245 & 10.420 & 2,56 & $\cdots$ \\
\hline Days ice free & 0.867 & 0.498 & 0.224 & 9.355 & 2,56 & $\cdots$ \\
\hline Salinity & 0.174 & 0.985 & 0.200 & 8.250 & 2,56 & $\cdots$ \\
\hline Longitude & -0.079 & 0.997 & 0.200 & 8.249 & 2,56 & $\cdots$ \\
\hline Sampling day & -0.064 & 0.998 & 0.194 & 7.977 & 2,56 & $\cdots$ \\
\hline Duration haul & - & - & 0.059 & 2.813 & 2,56 & ns \\
\hline Sample depth & - & - & 0.051 & 2.567 & 2,56 & ns \\
\hline
\end{tabular}

The other species previously shown to have close associations with E. crystallorophias and gammarids are the larvae of Pleuragramma antarcticum and Pagetopsis macropterus. Ichthyoplankton were not included in the present study as they were the subject of a separate study (Williams 1992).

The pteropod Limacina helicina and the salp Ihlea racovitzai were identified previously as species associated with either the neritic or main oceanic communities (Fig. 13). In this study, L. helicina was distributed widely throughout the study area, but was more abundant in the shelf waters where it was an abundance species indicator. Siegel \& Piatkowski (1990) also reported neritic and oceanic distributions for this species. I. racovitzai was dissociated from all other species.
It was also widely distributed with no significantly high abundances in any particular area. Neither species can be considered as a reliable indicator species.

Pleurobrachia pileus was the first species of ctenophore to be included in analyses of Prydz Bay species associations. Past abundances of ctenophores have been very low, i.e. $<4 \%$ numerical dominance for any site. This species primarily had a neritic distribution occurring at 9 of the on-shelf sites and only at 1 oceanic site immediately off the shelf. $P$. pileus was dissociated from other species but did exhibit a closer affinity with the neritic groups than with oceanic species (Fig. 12). This species, however, has been described as having a cosmopolitan distribution (Moser 1909, O'Sullivan 1986).
Fig. 11. Dendrogram of the inverse cluster analysis comparing dominant species. The Bray-Curtis dissimilarity index was used for the comparison with UPGMA linkage, after standardizing species abundance (Eq. 3). Six groups were defined at $70 \%$ dissimilarity

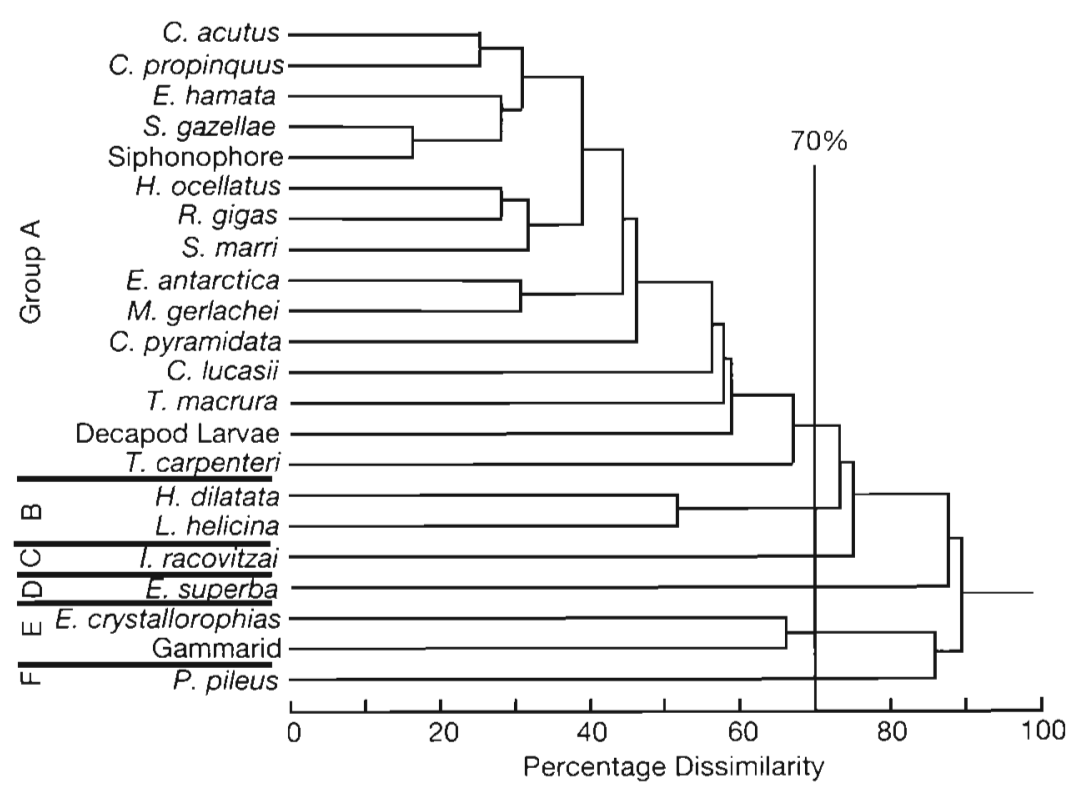




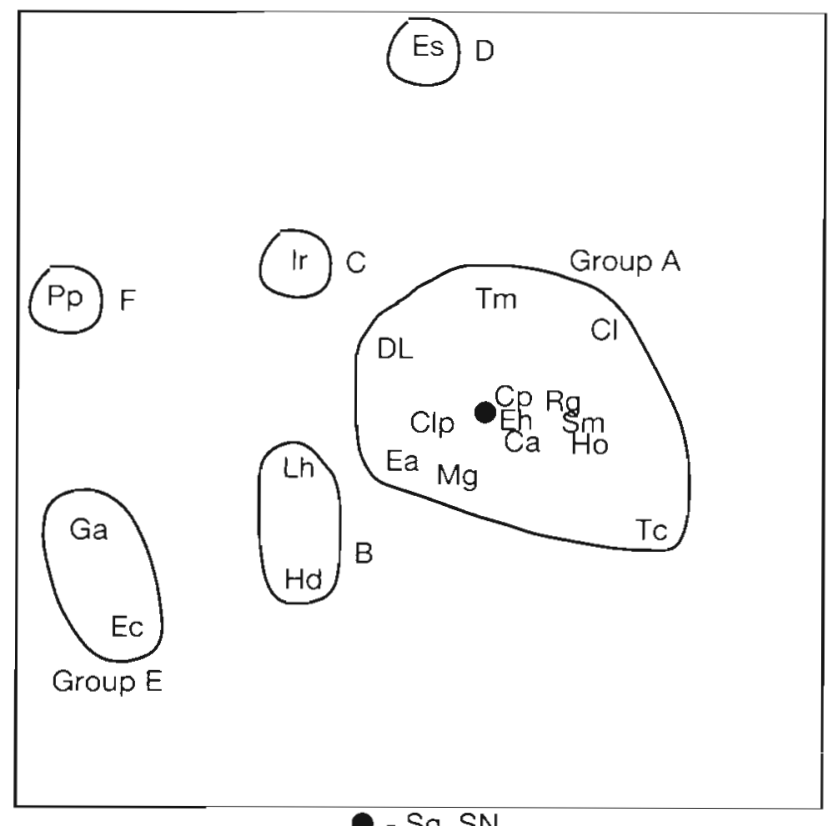

Sg, SN

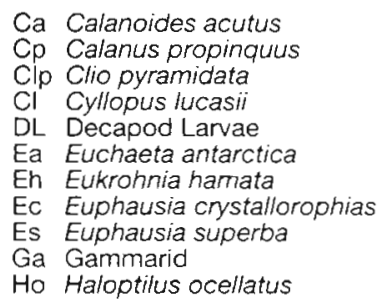

Hd Hyperiella dialtata

ir thiea racovitzai

Lh Limacina helicina

Mg Metridia gerlachei

Pp Pleurobrachia pileus

Rig Rhincalanus gigas

$\mathrm{Sg}$ Sagitta gazellae

Sm Sagitta marri

SN Siphonophore

Tm Thysanoessa macrura

Tc Tomopteris carpenteri

Fig. 12. NMDS inverse ordination plot comparing dominant species. Respective cluster groups identified in Fig. 11 are superimposed. Axis scales are relative in NMDS and therefore are not shown. Stress value $=0.16$

Euphausia superba exhibited a distinct dissociation from all other species (Fig. 12). In 1981 and 1985, krill were also clearly dissociated from other zooplankton, whereas in 1982 krill formed a distant association with neritic species and a more substantial association with the main oceanic community species in 1987 (Hosie 1994). However, in those latter 2 surveys, and also in 1981, E. superba was a significant abundance species indicator of geographic areas distinct from those dominated by neritic and oceanic zooplankton communities. The krill-dominated community was subsequently defined on the basis of this species' demonstrated dissociation and geographic dominance.

\section{Geographic variability}

While there is clear consistency in the species associations between the present and past surveys in Prydz Bay, the same cannot be said of the geographic distrib- utions of the communities. Most notable was the apparent absence of the krill-dominated community, despite the clear dissociation exhibited by this species in Fig. 12. This community is usually located along the continental shelf edge, between the oceanic and neritic communities, extending into shelf waters as far south as $67^{\circ} 30^{\prime} \mathrm{S}$ as seen in 1982 (Hosie 1994). In this study adult krill were primarily confined to the waters north of the continental shelf edge. The few krill found on the shelf were predominantly juvenile. As mentioned above, a characteristic of the krill-dominated community is the significant high abundance of krill, but an additional characteristic is the very low abundance of non-krill zooplankton compared with other areas. Krill thus form the majority component of catches. In 1981, 1982 and 1987, when the krill-dominated community was evident, mean krill abundances represented 80,68 and $57 \%$ of the mean total zooplankton abundance respectively. Krill were in higher abundance in station Group 2a, where they were also a frequency species indicator distinguishing Group 2a from $2 b$. However, the non-krill species composition and associated high abundances clearly identified Group $2 \mathrm{a}$ as the main oceanic community. Further, krill represented only $10 \%$ of the total zooplankton abundance and the ANOVA/SNK analyses showed that the higher abundance of krill in that area was not significant.

The station group with both the lowest non-krill zooplankton abundance and the highest proportion of krili was Group 2b. Krill represented $35 \%$ of the mean total zooplankton abundance, which is much lower than other years when the krill-dominated community was prominent. By definition then Group $2 b$ should represent the krill-dominated community, even though krill abundance was not significantly high. This being the case, the krill-dominated community which normally separates the neritic and oceanic communities was apparently displaced to the west.

Priddle et al. (1988) provided evidence that long periods of low krill abundances often occurred 2 to 3 times a decade in the Scotia Sea-Bransfield Strait area. These decreases in abundance were considered to be a result of changes in distribution rather than due to mortality. The January 1985 survey was similar to the present study with low krill abundances, albeit based on a much lower sampling resolution, and the krill-dominated community was not obvious (Hosie 1994). Assuming that the krill community distribution observed in the present study and 1985 were anomalous, there is insufficient data to indicate whether this is a regular phenomenon as observed in the Atlantic sector.

In addition to the unexpected distribution of krill, it is worth noting that krill collected during the present study were considered to be in poorer physiological 
Fig. 13. Zooplankton communities previously defined for the Prydz Bay region, based on macroscale surveys (from Hosie 1994). Shading within each box (i.e. each assemblage) corresponds to the shaded areas in Fig. 9 where that assemblage predominated Note: the northern oceanic community was not sampled during the present survey
NORTHERN OCEANIC COMMUNITY

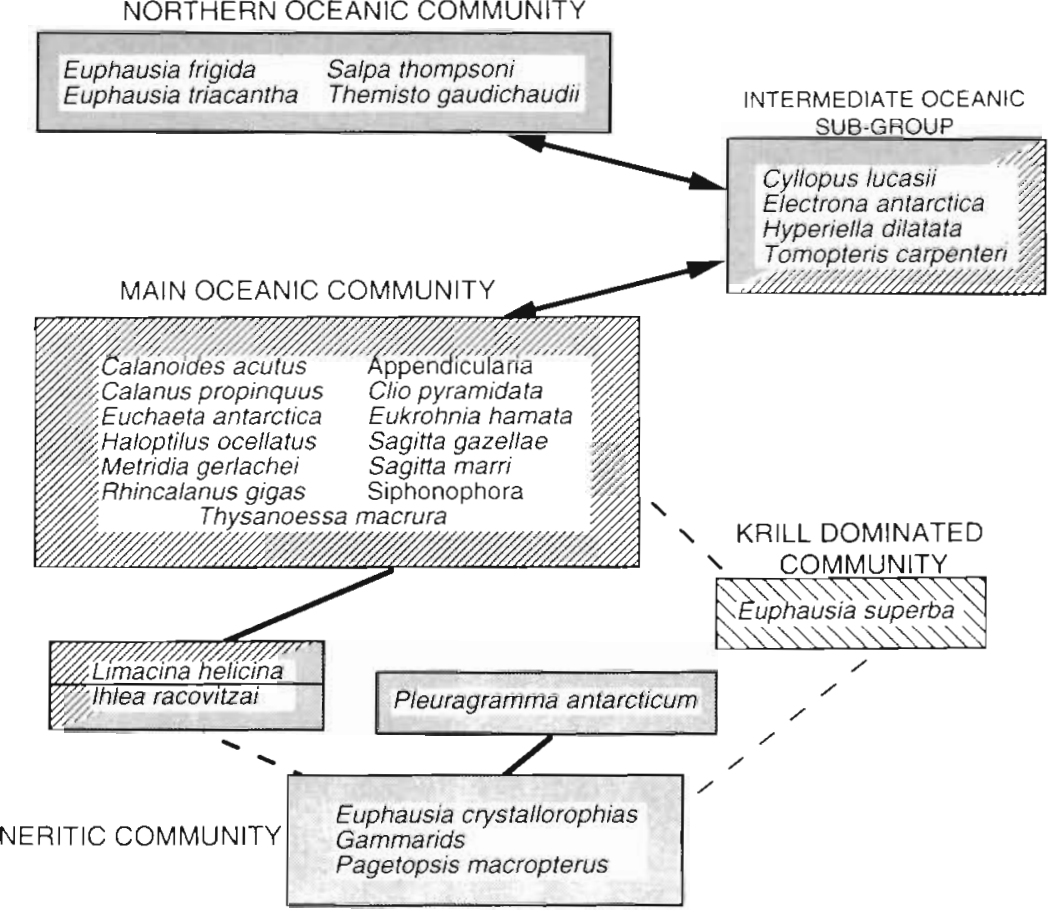

condition than specimens collected at a similar time in 1992 from Prydz Bay (Nicol et al. 1992). The 1992 krill had much higher growth rates and lipid content than krill collected in 1991.

\section{Controlling factors}

A number of parameters were identified (Table 4) which may control the observed zooplankton community distributions. However, it needs to be borne in mind when interpreting these results that a significant time component was introduced into the data set, indicated by 'Sampling Day' explaining $19 \%$ of the data variation. During the course of sampling, some characteristic of the communities had probably changed, e.g. distribution or composition. This further highlights the need for brevity in the sampling period when studying zooplankton communities and causal effects (Hosie 1994).

Strong latitudinal zonation was evident in the distribution patterns which is a consistent feature of all of the previous surveys in Prydz Bay. Some longitudinal zonation was also exhibited in the 2 off-shore station groups. Longitudinal zonation was observed in only 1 previous survey in March 1987 (Hosie 1994) when the main oceanic community was concentrated in the eastern part of the Prydz Bay region, probably by the northeasterly current shown in Fig. 3b. The result was an east-west separation of the main oceanic-and krill- dominated communities, similar to that seen in the present study. There is no clear indication that a similar north-easterly current caused the 1991 zonation, i.e. concentrating the main oceanic community in the east. The observed distributions of Groups 2a \& 2 b do have some correspondence with the geostrophic water flow shown in Fig. 2a. Station Group 2b, as shown in Fig. 9, was positioned in the centre of the Prydz Bay gyre, although there is no knowledge of how far west or north Group $2 b$ extended. The distribution of the main oceanic community corresponds with the eastern part of the gyre (Fig. 3a). The southward water flow would explain this communities distribution extending into shelf waters between $73^{\circ}$ and $77^{\circ} \mathrm{E}$, although there appears to be little evidence of this in temperature profiles. This in turn may have contributed to the displacement of the krill community. It would also suggest that the northeasterly current was either not present or was not influential in the dispersion of plankton.

The northeasterly current was proposed as a major dispersal route for Euphausia superba larvae (Hosie 1991). After the completion of the present gridded survey, a Hardy continuous plankton recorder (CPR) was deployed to collect E. superba larvae along that dispersal route. Two RMT 1 ( $1 \mathrm{~m}^{2}, 300 \mu \mathrm{m}$ mesh) trawls were carried out to supplement the CPR survey. The trawl sites $\left(64^{\circ} 10^{\prime} \mathrm{S}, 83^{\circ} 59^{\prime} \mathrm{E}\right.$; $\left.64^{\circ} 01^{\prime} \mathrm{S}, 84^{\circ} 34^{\prime} \mathrm{E}\right)$ were centred in an area where very high abundances were observed in March 1987 (Hosie et al. 1991). The 2 RMT 1 hauls produced very few larvae, and only 7 calyptopis 
stage larvae were collected by the CPR (authors' unpubl. data). The paucity of krill further suggests that there was no effective northeasterly current in 1991.

Temperature was a factor that explained some of the variation in other seasons, January to March 1981 , November to December 1982 and January 1985 (Hosie 1994). These were the larger geographic surveys encompassing the distributions of all 4 zooplankton communities (Fig, 13) and large temperature gradients. In the 1991 study, temperature explained a much more substantial amount of the variation in the data $(52 \%)$, suggesting temperature has a greater influence in controlling zooplankton at the mesoscale level. Numerous species have known temperature ranges (Foxton 1971, Lomakina 1966, Kittel \& Stepnik 1983, Everson 1984). For example, Ihlea racovitzai has a wide circumpolar distribution but is more abundant in $<0^{\circ} \mathrm{C}$ water and would seem more so in $<-1{ }^{\circ} \mathrm{C}$ water (Foxton 1971). Many other species, including copepods, have wide circumpolar distributions but still exhibit preferences for warmer or colder waters (Everson 1984). Euphausia crystallorophias has been described as a cold-water, stenothermic species (Lomakina 1966). The continental shelf edge is an area of rapid transition between zooplankton communities and also approximates the boundary between 2 distinct temperature regimes. South of the shelf edge, temperatures were uniformly cold, generally $<-1.6^{\circ} \mathrm{C}$. The E. crystallorophias-dominated neritic community was located entirely within that temperature regime. There was a more complex temperature zone, north of the shelf edge, with 3 discrete water masses in the upper $200 \mathrm{~m}$ - summer surface water, Antarctic winter water, and circumpolar deep water. Temperatures in this area ranged from -1.8 to $+2.1^{\circ} \mathrm{C}$. It was in this zone that the krill-dominated community and the more diverse main oceanic community occurred. There was no obvious temperature pattern in the offshore area (Figs. $4 \& 10$ ) that corresponds with, and thus would distinguish, the distribution patterns of the krill and main oceanic communities. It could be argued that temperature was only correlated with the zooplankton NMDS scores, i.e. there was no causal relationship. Both the zooplankton community distributions and temperature had obvious latitudinal patterns. Fig. 8 shows the close alignment between the temperature and latitudinal regressions. However, the strong correlation between temperature and the zooplankton NMDS scores, and the apparent separation of the communities in relation to temperature shown in Fig. 10, would suggest that temperature may be a major factor in separating the neritic and oceanic communities.

Salinity was one parameter not particularly consistent in explaining zooplankton patterns - only once in the previous 4 macroscale surveys, in January 1985
$(28 \%)$, and now in this study $(20 \%)$. Fig. 8 suggests that salinity may have had an east-west influence on the community distribution patterns, i.e. in the geographic separation of the krill and main oceanic communities. Comparison of the isohalines in Fig. 5 and community distributions (Fig. 9) reveal no obvious correspondence in the respective patterns, although Fig. 10 indicates that the krill-dominated community may occupy a narrower salinity range compared to the main oceanic community. It remains to be determined if salinity has anything other than a minimal effect on community distributions

Phytoplankton would naturally be expected to have some influence on the distribution of the zooplankton, especially in combination with pack-ice (Hart 1942, Smetacek et al. 1990, Smith \& Schnack-Schiel 1990). In this study chl a explained a reasonable amount of the data variation $(30 \%)$, which is commensurate with the previous macroscale surveys where chl a also explained much of the zooplankton patterns (27 to $38 \%$ ) observed between November and March (Hosie 1994). The exception was the end of summer March 1987 when chl a appeared to have no influence on zooplankton distributions and, instead, water circulation was the single important controlling factor. Overall, chl a would seem to be the one environmental parameter that consistently explains zooplankton distributions for most of the summer period.

There is obvious consistency through all of the surveys in relation to the amount of variation in the zooplankton patterns explained by $\mathrm{chl}$ a. There is also consistency in the general geographic distribution of phytoplankton with the highest chl a values always found in the waters of the continental shelf. The 1991 season was different in that chl a levels south of the shelf edge were higher than previously recorded, and concentrated in a much shallower mixed layer between 0 and $30 \mathrm{~m}$ depth than usually observed down 60 to $100 \mathrm{~m}$ (Wright 1987, S. W. Wright pers. comm. 1991). North of the shelf, the 1991 levels were much lower than previously recorded for the same area of sampling (Wright 1987). This immediately begs the question, were the anomalous zooplankton distributions, specifically the displacement of the krill-dominated community, a result of the equally unusual phytoplankton abundances? The manner by which phytoplankton influences zooplankton distributions is yet to be established, especially the role that phytoplankton might play in the geographic separation of Euphausia superba and E. crystallorophias and their respective communities.

The 'Ice Recession' and 'Days Ice Free' parameters both exhibited a distinct latitudinal pattern and, like temperature mentioned above, these parameters may only be correlated with zooplankton distributions, i.e. no genuine causal effect. Notably, the pattern of ice 
recession observed in 1991 was quite different from that usually seen. An examination of US Navy-NOAA ice maps showed that a large polynya usually appears by early December in the southern part of Prydz Bay near the Amery Ice Shelf. This is at a time when the area to the north is still extensively covered by ice and the northern ice edge is still moving south. The occurrence of a large polynya in this area, or at least light pack-ice, has also been consistently observed from oceanographic and supply vessels operating in Prydz Bay (Smith et al. 1984, Streten \& Pike 1984). Ice then dissipates north towards the shelf edge to meet the southward receding ice edge. This was the pattern observed in the 1984-1985 summer when ice recession explained $60 \%$ of the zooplankton data (Hosie 1994). In the 1990-1991 summer, ice dissipated only from north to south - no polynya formed in the south and there was no northward dissipation of ice. Much of the pack ice then remained in the Bay throughout the summer period. Light pack of 2 to $4 / 10$ cover extended north and southwest of Davis. A more substantive cover of ice remained in the west of the Bay, extending around Cape Darnley to the west and north of the cape to the shelf edge. Ice in this area was sufficiently dense, up to 9 to $10 / 10$ cover, to necessitate a deviation in the $70^{\circ} 30^{\prime} \mathrm{E}$ transect (Fig. 1, Stns 54 to 56).

The persistent pack-ice, the absence of ice break out from the south, the shallow mixed layer and subsequently very high chl a levels are all indicative of the calm weather conditions experienced during the survey period. There is, however, no proof that the ice or oceanographic/phytoplankton events produced the unexpected zooplankton community patterns, but they provide further evidence that 1991 was perhaps an anomalous season. The challenge for future research will be to actually establish the causal effects, if in fact cause-and-effects between environmental parameters and pelagic communities can be proved adequately.

Acknowledgements. We are extremely grateful to Dr S. W. Wright for providing unpublished chl a data and to Drs R. Nunes Vaz and G. Lennon for providing their unpublished results on horizontal water circulation. We are also grateful to the captain and crew of the RSV 'Aurora Australis' for their interest and assistance. Special thanks go to the following for their assistance in the collection and on-board processing of samples: R. Williams, S. Davenport, P. Geijsel, A. McEldowney, M. Stolp, T. Stranks, K. Gowlett-Holmes; Drs S. Nicol, A. Constable, A. Tanimura, C. C. Lu and W. Zeidler, and Gear Officers R. Burbury and A. Tabor

\section{LITERATURE CITED}

Atkinson, A., Ward, P., Peck, J. M., Murray, A. W. A. (1990). Mesoscale distribution of zooplankton around South Georgia. Deep Sea Res. 37: 1213-1227
Baker, A. de C., Clarke, M. R., Harris, M. J. (1973). The NIO combination net (RMT $1+8$ ) and further developments of rectangular midwater trawls. $J$ mar. biol. Ass. U.K. 53: $167-184$

Boden, B. P. (1985). The South African SIBEX I cruise to the Prydz Bay region, 1984. VIII. The plankton encountered during the survey. S. Afr. J. Antarct. Res. 15: 28-32

Boysen-Ennen, E., Piatkowski, U. (1988). Meso- and macrozooplankton communities in the Weddell Sea, Antarctica. Polar Biol. 9: 17-35

Boysen-Ennen, E., Hagen, W., Hubold, G., Piatkowski, U. (1991). Zooplankton biomass in the ice-covered Weddell Sea, Antarctica. Mar. Biol. 111: 227-235

Brandt, S. B., Wadley, V. A. (1981). Thermal fronts as ecotones and zoogeographic barriers in marine and freshwater systems. Proc. Ecol. Soc. Aus. 11: 13-26

Bray, J. R., Curtis, J. T. (1957). An ordination of the upland forest communities of southern Wisconsin. Ecol. Monogr. 2 : $325-349$

Budnichenko, E. V., Khromov, N. C. (1988). Biomassa mezoplanktona, vozrastnoy sostav i raspredeleniye rukovodyashchikh form v svyazi so strukturoy vod b Moryach Sodruzhestva i Kosmanavtov. In: Kompleksniye issledovaniya ekosistemi pelagiali v Moryach Sodruzhestva i Kosmonavtov. Sbornik nauchnich trudov. [Multi-disciplinary investigations of pelagic ecosystems in the Sodruzhestva and Kosmonavtov Seas. Collection of scientific papers] VNIRO Publishers, Moscow, p. 83-107 (in Russian)

Conover, R. J., Huntley, M. (1991). Copepods in ice-covered seas - distribution, adaptations to seasonally limited food, metabolism, growth patterns and life cycle strategies in polar seas. J. mar. Syst. 2: 1-41

Everson, I. (1984). Zooplankton. In: Laws, R. M. (ed.) Antarctic ecology, Vol. 2. Academic Press, London, p. 463-490

Field, J. G. Clarke, K. R., Warwick, R. M. (1982). A practical strategy for analysing multispecies distribution patterns. Mar. Ecol. Prog. Ser. 8: 37-52

Foster, B. A., Cargill, J. M., Montgomery, J. C. (1987). Planktivory in Pagothenia borchgrevinki (Pisces: Nototheniidae) in McMurdo Sound, Antarctica. Polar Biol. 8: 49-54

Foxton. P. (1971). On Ihlea magellanica (Apstein) (Tunicata: Salpidae) and Ihlea racovitzai (van Beneden). 'Discovery' Rep. 35: 179-198

Fukuchi, M., Tanimura, A., Ohtsuka, H. (1985). Zooplankton community conditions under sea ice near Syowa Station, Antarctica. Bull. mar. Sci. 37: 518-528

Gauch. H. G. Jr (1982). Multivariate analysis in community ecology. Cambridge Studies in Ecology. Cambridge University Press, Cambridge

Gray, J. S., Aschan, M., Carr, M. R., Clarke, K. R., Green, R. H., Pearson, T. H., Rosenberg, R., Warwick. R. M. (1988). Analysis of community attributes of the benthic macrofauna of Frierfjord/Langesundfjord and in a mesocosm experiment. Mar. Ecol. Prog. Ser. 46: 151-165

Green, K., Williams, R. (1986). Observations on food remains in faeces of elephant, leopard and crabeater seals. Polar Biol. 6: 43-45

Hart, T. J. (1942). Phytoplankton periodicity in Antarctic surface waters. 'Discovery' Rep. 21. 261-356

Haury, L. R., McGowan, J., Wiebe, P. (1977). Patterns and processes in the time-space scales of plankton distributions. In: Steele, J. H. (ed.) Spatial patterns in plankton communities. Plenum Press, New York, p. 227-327

Hopkins, T. L. (1971). Zooplankton standing crop in the Pacific sector of the Antarctic. Antarct. Res. Ser. 17: $347-362$ 
Hosie, G. W. (1991). Distribution and abundance of euphausiid larvae in the Prydz Bay region, Antarctica. Antarct. Sci. 3: 167-180

Hosie, G. W. (1994). The macrozooplankton communities in the Prydz Bay region, Antarctica. In: El-Sayed, S. Z. (ed.) Southern Ocean ecology: the BIOMASS perspective Cambridge University Press, Cambridge, p. 93-123

Hosie, G. W., Ikeda, T., Stolp, M. (1988). Distribution, abundance and population structure of the Antarctic krill (Euphausia superba Dana) in the Prydz Bay region, Antarctica. Polar Biol. 8: 213-224

Hosie, G. W., Kitchener, J., Stolp, M., Cochran, T G., Williams, R. (1991). AAMBER 86/87 Cruise krill/zooplankton sampling data. Aust. natl Antarct. Res. Exped. Res Notes 79: 1-54

Hubold, G., Ekau. W. (1990). Feeding patterns of post-larval and juvenile notothenioids in the southern Weddell Sea (Antarctica). Polar Biol. 10: 255-260

Hubold, G., Hempel, I., Meyer, M. (1988). Zooplankton communities in the southern Weddell Sea. Polar Biol. 8: $225-233$

Jacka, T. H. (1983). A computer data base for Antarctic sea ice extent. Aust. natl Antarct. Res. Exped. Res. Notes 13: 1-54

Jongman, R. H. G., ter Braak, C. J. F., van Tongeren, O. F. R. (1987). Data analysis in community and landscape ecology. Pudoc, Wageningen

Kawamura, A. (1986). Has marine Antarctic ecosystems changed? - A tentative comparison of present and past macrozooplankton abundances. Mem. natl Inst polar Res. Tokyo 40: 197-211

Kellermann, A. (1987). Food and feeding ecology of postlarval and juvenile Pleuragramma antarcticum (Pisces; Notothenioidei) in the seasonal pack ice zone off the Antarctic Peninsula. Polar Biol. 7: 307-315

Kerry, K. R., Woehler. E. J., Robb, M. S. (1987). Oceanographic data: Prydz Bay region - SIBEX II, MV Nella Dan, January 1985. Aust. natl Antarct. Res. Exped. Res. Notes 53: 1-122

Kittel, W. Stepnik, R. (1983). Distribution of Euphausia crystallorophias, E. frigida, E. triacantha and Thysanoessa macrura (Crustacea, Euphausiacea) in the southern Drake Passage and Bransfield Strait in February and March 1981. Pol. Polar Res. 4: 7-19

Kruskal, J. B., Wish, M. (1978). Multidimensional scaling. Sage Publications, Beverley Hills

Lomakina, N. B. (1966). The euphausiid fauna of the Antarctic and notal regions. Biological Reports of the Soviet Antarctic Expedition (1955-58) 2: 260-342

Lubimova, T. G., Makarov, R. R., Maslenikov, V. V., Shevtsov, V. V., Shust, K. V. (1985). The ecological peculiarities, stocks and role of E. superba in the trophic structure of the Antarctic ecosystem. Selected Paper Presented to the Scientific Committee CCAMLR 1982-1984 Part II. CCAMLR (Commission for the Conservation of Antartic Marine Living Resources), Hobart, p. 391-505

Mackintosh, N. A. (1973). Distribution of post-larval krill in the Antarctic. 'Discovery' Rep. 36: 95-156

Marr, J. W. S. (1962). The natural history and geography of the Antarctic krill (Euphausia superba). 'Discovery' Rep. 32: $33-464$.

Middleton, J. H., Humphries, S. E. (1989). Thermohaline structure and mixing in the region of Prydz Bay, Antarctica. Deep Sea Res. 36: 1255-1266

Mills, E. L. (1969). The community concept in marine zoology, with comments on continua and instability in some marine communities: a review. J. Fish. Res. Bd Can. 26: $1415-1428$
Moser, F. (1909). Die Ctenophoren der Deutschen SüdpolarExpedition 1901-1903. Dtsch Sudpol.-Exped. 11 1-192

Nicol, S., Stolp, M., Cochran, T., Geijsel, P., Marshall, J. (1992). Growth and shrinkage of Antarctic krill Euphausia superba from the Indian Ocean sector of the Southern Ocean during summer. Mar. Ecol. Prog. Ser 89: 175-181

O'Sullivan, D. (1986). A guide to the ctenophores of the Southern Ocean and adjacent waters. Aust. natl Antarct. Res. Exped. Res. Notes 36:1-43

Pakhomov, E. A. (1989). Raspredeleniye makroplanktona v tsentral'noy chasti Indiiskogo Sektora Yuzhnogo Okeana $\checkmark$ letniye seson'i 1984-86. Antarktika 28: 145-157 (in Russian)

Piatkowski, U. (1989a). Macrozooplankton communities from Weddell Sea surface waters, Antarctica. Pesq. antárt. bras. 1: $1-10$

Piatkowski, U. (1989b). Macroplankton communities in Antarctic surface waters: spatial changes related to hydrography. Mar. Ecol. Prog. Ser. 55: 251-259

Pommeranz, T., Hermann, C., Kühn, A. (1982). Mouth angle of the Rectangular Midwater Trawl (RMT1+8) during paying out and hauling. Meeresforsch. 29: 267-274

Priddle, J., Croxall, J. P., Everson, I., Heywood, R. B., Murphy, E. J., Prince, P. A., Sear, C. B. (1988). Large-scale fluctuations in distribution and abundance of krill - a discussion of possible causes. In: Sahrhage, D. (ed.) Antarctic Ocean and resources variability. Springer-Verlag, Berlin, p. 169-182

Puddicombe, R. A., Johnstone, G. W. (1988). The breeding season diet of Adelie penguins at the Vestfold Hills, East Antarctica. Hydrobiologia 165: 239-253

Roe, H. S. J., Baker, A. de C., Carson, R. M., Wild, R., Shale, D. M. (1980). Behaviour of the Institute of Oceanographic Science's rectangular midwater trawls: theoretical aspects and experimental observations. Mar. Biol. 56: 247-259

Schnack, S. B., Marschall, S., Mizdalski, E. (1985). On the distribution of copepods and larvae of Euphausia superba in Antarctic waters during February 1982. Meeresforsch. 30: $251-263$

Siegel, V. (1986). Untersuchungen zur Biologie des antarktischen Krill, Euphausia superba, im Bereich der Bransfield Straße und angrenzender Gebiete. Mitt. Inst. Seefisch. 38: $1-244$

Siegel, V., Piatkowski, U. (1990). Variability in the macrozooplankton community off the Antarctic Peninsula. Polar Biol. 10: 373-386

Smetacek, V., Scharek, R., Nöthig, E.-M. (1990). Seasonal and regional variation in the pelagial and its relationship to the life history cycle of krill. In: Kerry, K. R., Hempel, G. (eds.) Antarctic ecosystems. Ecological change and conservation. Springer-Verlag, Berlin, p. 103-114

Smith, N. R., Dong, Z., Kerry, K. R., Wright, S. (1984). Water masses and circulation in the region of Prydz Bay, Antarctica. Deep Sea Res. 31: 1121-1147

Smith, S. L., Schnack-Schie\}, S. B. \{1990\}. Polar zooplankton. In: Smith, W. O. Jr (ed.) Polar oceanography, Part B, Chemistry, biology, and geology. Academic Press, San Diego, p. 527-598

Steedman, H. F. (1976). Zooplankton fixation and preservation. Monogr. oceanogr. Methodol. 4: 1-359

Streten, N. A., Pike, D. J. (1984). Some observations of the sea-ice in the southwest Indian Ocean. Aust. Met. Mag. 32: 195-206

Tanimura, A., Fukuchi, M., Hoshiai, T (1986). Seasonal change in the abundance of zooplankton and species composition of copepods in the ice-covered sea near Syowa station, Antarctica. Mem. natl Inst. polar Res. Tokyo 40: $212-220$ 
Terazaki, M. (1989). Distribution of chaetognaths in the Australian sector of the Southern Ocean during the BIOMASS SIBEX cruise (KH-83-4). Proc. NIPR Symp. Polar Biol. 2: $51-60$

Terazaki, M., Wada, M. (1986). Euphausiids collected from the Australian sector of the Southern Ocean during the BIOMAS SIBEX cruise (KH-83-4). Mem. natn. Inst. polar Res. Tokyo 40: $97-109$

Voronina, N. M. (1967). The zooplankton of the Southern Ocean; some study results. Oceanology 6: 557-563

Williams, R. (1985). Trophic relationships between pelagic fish and euphausiids in Antarctic waters. In: Siegfried, W. R., Condy, P. R., Laws, R. M. (eds.) Antarctic nutrient cycles and food webs. Springer-Verlag, Berlin, p. $452-459$

Williams, R. (1989). Australian research on Antarctic bird and seal diets. Selected papers presented to the scientific committee of CCAMLR 1988, SC-CAMLR-SSP/5, Part II.

This article was submitted to the editor
CCAMLR (Commission for the Conservation of Antarctic Marine Living Resources), Hobart, p. 231-249

Williams, R. (1992). Studies on the fish of the Prydz Bay region. 1990-91 Australian Antarctic Research Program. Initial summary of research activity. Australian Antarctic Division, Hobart, p. 148-149

Wright, S. W. (1987). Phytoplankton pigment data: Prydz Bay region - SIBEX II, MV 'Nella Dan', January 1985. Aust. natl Antarct. Res. Exped. Res. Notes 58: 1-102

Yamada, S., Kawamura, A. (1986). Some characteristics of the zooplankton distribution in the Prydz Bay region of the Indian Ocean sector of the Antarctic Ocean in the summer of 1983/84. Mem. natl Inst. polar Res. Tokyo 44: 86-95

Zar, J. H. (1984). Biostatistical analysis, 2nd edn. PrenticeHall, Englewood Cliffs

Zmijewska, M. I. (1983). Copepoda (Calanoida) from Prydz Bay (Antarctica, Indian Ocean Sector). Pol. Polar Res. 4: $33-47$

Manuscript first received: July 14, 1993

Revised version accepted: December 13, 1993 